\title{
Single Cell Gene Expression Profiling in Alzheimer's Disease
}

\author{
Stephen D. Ginsberg, ${ }^{* \dagger *}$ Shaoli Che, ${ }^{* \dagger}$ Scott E. Counts, ${ }^{\S}$ and Elliott J. Mufson ${ }^{\S}$ \\ *Center for Dementia Research, Nathan Kline Institute, ${ }^{\dagger}$ Departments of Psychiatry and ${ }^{*}$ Physiology and Neuroscience, New \\ York University School of Medicine, Orangeburg, New York; and ${ }^{\S}$ Department of Neurological Sciences, Rush University \\ Medical Center, Chicago, Illinois
}

Summary: Development and implementation of microarray techniques to quantify expression levels of dozens to hundreds to thousands of transcripts simultaneously within select tissue samples from normal control subjects and neurodegenerative diseased brains has enabled scientists to create molecular fingerprints of vulnerable neuronal populations in Alzheimer's disease (AD) and related disorders. A goal is to sample gene expression from homogeneous cell types within a defined region without potential contamination by expression profiles of adjacent neuronal subpopulations and nonneuronal cells. The precise resolution afforded by single cell and population cell RNA analysis in combination with microarrays and real-time quantitative polymerase chain reaction (qPCR)-based analyses allows for relative gene expression level comparisons across cell types under different experimental conditions and disease progression. The ability to analyze single cells is an important distinction from global and regional assessments of mRNA expression and can be applied to optimally prepared tissues from animal models of neurodegeneration as well as postmortem human brain tissues. Gene expression analysis in postmortem $\mathrm{AD}$ brain regions including the hippocampal formation and neocortex reveals selectively vulnerable cell types share putative pathogenetic alterations in common classes of transcripts, for example, markers of glutamatergic neurotransmission, synaptic-related markers, protein phosphatases and kinases, and neurotrophins/neurotrophin receptors. Expression profiles of vulnerable regions and neurons may reveal important clues toward the understanding of the molecular pathogenesis of various neurological diseases and aid in identifying rational targets toward pharmacotherapeutic interventions for progressive, late-onset neurodegenerative disorders such as mild cognitive impairment (MCI) and AD. Key Words: Microarray, neurodegeneration, RNA amplification, aging, qPCR, mild cognitive impairment, molecular fingerprint, postmortem human brain.

\section{INTRODUCTION}

Azheimer's disease (AD) is the most common cause of dementia worldwide, and it affects approximately $5 \%$ of people over the age of 60 and $50 \%$ of people over the age of $85 .^{1,2}$ Azheimer's disease is characterized clinically by progressive cognitive decline, loss of executive function, and memory deficits eventually leading to incapacitating dementia before death, and pathologically by the deposition of filamentous material in intracellular and extracellular compartments in the form of neurofibrillary tangles (NFTs), neuropil threads (NTs), and senile plaques (SPs), predominantly within the hippocampal formation and neocortex. ${ }^{3-6}$ Although there is widespread decline in vari-

Address correspondence and reprint requests to: Stephen D. Ginsberg, Ph.D., Center for Dementia Research, Nathan Kline Institute, New York University School of Medicine, 140 Old Orangeburg Road, Orangeburg, NY 10962. E-mail: ginsberg@nki.rfmh.org. ous neurotransmitter systems as $\mathrm{AD}$ progresses, most consistent deficits and cell loss are observed in long projection neurons, including cholinergic basal forebrain (CBF) neurons of the nucleus basalis (NB), ${ }^{7-10}$ glutamatergic neurons within the entorhinal cortex and neocortex, ${ }^{11,12}$ and glutamatergic layer II/III and V corticocortical projection neurons of secondary association cortex,${ }^{13}$ leading to regionally specific synaptic and connectivity-based degeneration. A diagnosis of $\mathrm{AD}$ is made postmortem on aged patients who display progressive cognitive decline, neuron loss, and the presence of abundant SPs and NFTs. ${ }^{14,15}$ Although dementia associated with unsuccessful aging has been documented for centuries, ${ }^{16}$ it was Dr. A. Alzheimer ${ }^{17}$ who first described the clinicopathological features of the disease that today bears his name. Recent advances in genetics, cell biology, and molecular neuroscience have provided novel approaches to evaluate the neurodegenerative processes underlying the pathophysiology of AD. 


\section{ALZHEIMER'S DISEASE GENETICS: AMYLOID- $\beta$ PROTEIN PRECURSOR AND PRESENILIN}

Genetic studies of the familial forms of Alzheimer's disease (FAD) along with the more prevalent sporadic form of $\mathrm{AD}$ have demonstrated that the entity designated as $\mathrm{AD}$ is a heterogeneous disorder with differing etiologies that share similar clinical and pathological phenotypes. ${ }^{3,18}$ Notably, SP deposition is a potentially pathological process whereby amyloid fibrils of approximately $5-10 \mathrm{~nm}$ in diameter accumulate within extracellular compartments of the CNS, vasculature, and peripheral tissues in $\mathrm{AD}^{4,19}$ Amyloid fibrils are highly insoluble and display Congo red birefringence or thioflavine-S (TS) fluorescence due to a preferred $\beta$-pleated sheet conformation. The extracellular accumulation of abundant SPs within the hippocampal formation and neocortex of elderly people is a necessary prerequisite for the postmortem diagnosis of AD. ${ }^{14,15}$ Several proteins are associated with SPs in AD brain, including the nonamyloid component of plaques (NACP), a 35-amino-acid proteolytic fragment of the $\alpha$-synuclein protein found in Lewy bodies, ${ }^{20,21} \alpha 1$-anti-chymotrypsin, chromogranin A, serum amyloid $\mathrm{P}$, heparan sulfate proteoglycan, several complement proteins (e.g., Clq, C3c, and C5b-9), and apolipoprotein E (APOE) ${ }^{22-24}$ However, the major protein species purified from extracellular plaques (SPs and amyloid surrounding cerebral vasculature) are the $\sim 4$ $\mathrm{kDa}$ amyloid- $\beta$ peptide $\left(\mathrm{A} \beta\right.$ ) peptides. ${ }^{25,26}$ Although SPs are a distinguishing pathological hallmark of $\mathrm{AD}$, heterogeneity exists in their morphology and composition. Senile plaques are categorized as neuritic plaques or diffuse plaques. Neuritic plaques have a dense $\mathrm{A} \beta$-containing core and fibrillar corona, as well as an abundance of hyperphosphorylated tau-containing dystrophic neurites dispersed throughout the corona and core regions. Neuritic plaques are associated with inflammatory activation as microglial cells permeate the cytological boundaries of the fibrillar corona and reactive astrocytes are observed around the periphery. ${ }^{27-31}$ Neuritic plaques are found within the $\mathrm{AD}$ brain and are also observed readily by Congo red birefringence or TS staining. Diffuse plaques, as their name suggests, lack a definitive amyloid core, contain few or no dystrophic neurites, do not produce an inflammatory response, nor are they visualized as readily as neuritic plagues by Congo red or TS staining. Diffuse plaques are identified optimally via immunocytochemistry using antibodies directed against A $\beta$ peptides. ${ }^{32,33}$ Presently, little or no correlation has been found between the quantity of extracellular SPs and/or $A \beta$ burden and measures of cognitive/neurological dysfunction. ${ }^{34-36}$ In contrast, a consensus is beginning to emerge that implicates nonfibrillar intracellular $\mathrm{A} \beta$ oligomers consisting principally of $\mathrm{A} \beta(1-42)$ as toxic intermediates that cause biochemical and neuropathological alterations in the AD brain and mouse models of cerebral amyloidosis. ${ }^{37-40}$

In addition to $\mathrm{AD}$, several other neurological disorders involve cerebral amyloid deposition. For example, Down's syndrome (DS or Ts21) patients invariably develop AD pathology by their fourth decade of life and SPs have been identified in Ts 21 patients by early adolescence. ${ }^{41,42}$ The coincidence of AD pathology in Ts 21 and the localization of the amyloid- $\beta$ protein precursor (APP) gene to chromosome 21 was the initial impetus for genetic analyses of FAD on the chromosome 21 locus. Presently, 29 mutations in the APP gene account for a minor percentage of FAD kindreds (4 deemed to be nonpathogenic; Alzheimer Disease Mutation Database http://www.molgen.ua.ac.be/ADMutations), but provide genetic evidence for the abnormal function of APP processing and $\mathrm{A} \beta$ deposition in the pathogenesis of AD. ${ }^{43-45}$ Along these lines, mice overexpressing FADrelated APP transgenes display increased $\mathrm{A} \beta$ peptide (especially $\mathrm{A} \beta(1-42)$ production and plaque deposition. ${ }^{46-48}$

Autosomal dominant mutations in genes encoding presenilin 1 (PSEN1) on chromosome 14 and presenilin 2 (PSEN2) on chromosome 1 account for the majority of FAD kindreds identified to date. ${ }^{49-51}$ PSEN1 and PSEN2 are transmembrane proteins of approximately $50 \mathrm{kDa}$ that share $67 \%$ sequence homology and are localized primarily to the endoplasmic reticulum and Golgi apparatus by immunocytochemistry. ${ }^{50-52}$ PSEN1 and PSEN2 mRNA and protein are distributed throughout mouse, rat, monkey, and human tissues, including the brain, with notable enrichment in the hippocampus, entorhinal cortex, and cerebellum. ${ }^{52,53}$ PSEN1 is hypothesized to be an integral component of the $\gamma$-secretase complex (along with nicastrin, pen-2, and aph-1, among others) that mediates the intramembrane proteolysis of APP to generate $\mathrm{A} \beta$ peptides and carboxy-terminal fragments of APP (CTFs). ${ }^{54,55}$ Cell culture and transgenic mouse studies have also detected an interaction between mutations in the PSEN1 and PSEN2 genes observed in FAD kindreds and increased production of the amyloidogenic $A \beta$ fragment $[\mathrm{A} \beta(1-42)]{ }^{46,56,57}$ Specifically, an increased ratio of $\mathrm{A} \beta(1-42) / \mathrm{A} \beta(1-40)$ caused by defective presenilins may act as a seed or nidus for fibrillar $\mathrm{A} \beta$ deposition and intraneuronal accumulation, as $\mathrm{A} \beta(1-42)$ rapidly forms fibrils in vitro, is the principal component of SP lesions, and has been observed within intracellular stores. ${ }^{38,58-60}$ Presently, 158 mutations (3 nonpathogenic) have been identified within the PSEN1 gene, and 11 (1 nonpathogenic) mutations have been detected in the PSEN2 gene (Alzheimer Disease Mutation Database).

Not all known FAD kindreds have been linked to PSEN1, PSEN2, or APP mutations, therefore other mutations linked to FAD await identification. A successful 
method to delineate potential causal/susceptibility genes is linkage analysis using a genome-scan approach. This strategy employs microsatellite markers comprised of polymorphisms that likely represent random genetic variations. ${ }^{61}$ Microsatellite maps have been generated that span the entire genome, ${ }^{62}$ and research groups have used linkage-based approaches to find candidate genes associated with several progressive neuropathological disorders, including possible candidates for late-onset $\mathrm{AD}$ on chromosomes 10,12 , and $20 .{ }^{63-65}$ In addition, a multitude of mouse models of APP and PSEN1 (as well as transgenic mice expressing both mutant APP and PSEN1) overexpression have been generated ${ }^{40,46,48,56,66}$ that provide insight into potential mechanisms by which these proteins that are mutated in the FAD kindred may play a role in the pathophysiology of $\mathrm{AD}$.

\section{TAU MUTATIONS AND NEURODEGENERATIVE DISORDERS}

Tau is a low-molecular-weight microtubule-associated protein found in the CNS and peripheral nervous system and is localized primarily to axonal compartments in normal brain. ${ }^{67,68}$ Abnormally phosphorylated tau is observed within neurofibrillary lesions (NFTs, NTs, and dystrophic neurites) of the AD brain and other tangle-bearing disorders including Pick's disease, progressive supranuclear palsy, and corticobasal degeneration, among others. ${ }^{3,69}$ Cloning of the tau gene revealed that multiple tau isoforms are produced from a single gene on chromosome 17 through alternative mRNA splicing. ${ }^{70,71} \mathrm{Six}$ isoforms of tau protein are found in the adult human brain: three isoforms with three tandem microtubule binding repeats (3Rtau) and three isoforms with four tandem microtubule binding repeats (4Rtau) of 31 or 32 amino acids in the carboxy-terminus of the molecule, and these tandem repeat regions contain microtubule binding domains. ${ }^{70-72}$ Tau isoforms also differ by 29 or 58 amino acid inserts $(0,1$, or 2 inserts; FIG. 1$)$ in the amino-terminal region of the molecule. ${ }^{70-72}$ Tau promotes the polymerization of tubulin monomers into microtubules. ${ }^{72-74}$ Phosphorylation negatively regulates tau binding to microtubules. ${ }^{74}$ Phosphorylation sites on the tau molecule occur at many proline-directed serine/ threonine sites, although there are reports of phosphorylation at nonproline-directed sites. ${ }^{71,75,76}$ Mutations in the human tau gene were discovered in a group of frontotemporal dementias (FTDs) termed chromosome 17linked frontotemporal dementia and parkinsonism (FTDP-17) ${ }^{69,77-79}$ At present, 40 different mutations (18 nonpathogenic) within the tau gene that cause FTD have been identified (Alzheimer Disease Mutation Database), including missense mutations in exons $9,10,12$, and 13, as well as point mutations in the $5^{\prime}$ splice donor site of exon $10 .{ }^{69,80,81}$ Many of these mutations result in the

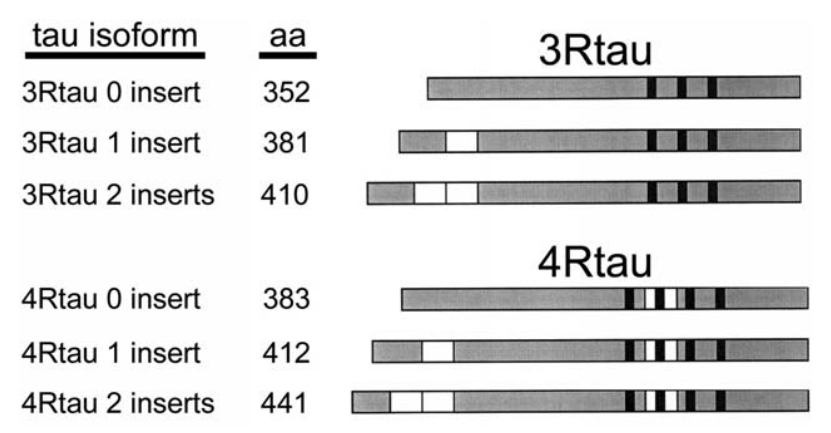

FIG. 1. Schematic diagram illustrating the six tau isoforms present in human brain. The number of amino terminal inserts $(0$, 1 , or 2 inserts; white boxes) is depicted along with the predicted amino acids (aa) for each isoform. Tau isoforms are presented in terms of microtubule binding repeats (3Rtau, black boxes; 4Rtau, black and white boxes illustrate the additional microtubule binding repeat of 4 Rtau). This schematic illustration is adapted from two of our previously published reports. ${ }^{3,73}$

intraneuronal accumulation of hyperphosphorylated tau and NFTs. Neuronal cell loss is also observed, although cell death does not always occur through an NFT-bearing mechanism. ${ }^{82,83}$ FTDP-17 kindreds display a wide phenotypic variety that may reflect the function (i.e., dysfunction and/or toxic gain of function) of individual tau mutations, as mutations in exons 9,10 , and 12 lie within the microtubule binding domains of tau, whereas mutations in exon 13 affect the carboxy-terminus of the microtubule binding region. ${ }^{78,82,84}$ Further understanding of the genetics of tauopathies may occur from investigations of genetically engineered animals including the htau, ${ }^{85,86} \mathrm{P} 301 \mathrm{~L},{ }^{87,88}$ and $\mathrm{R} 406 \mathrm{~W}^{89}$ mouse models.

\section{APOLIPOPROTEIN E AS A RISK FACTOR FOR AD}

In addition to the APP, PSEN1, and PSEN2 mutations found in FAD and the tau mutations found in FTD, the risk of developing sporadic $\mathrm{AD}$ ( $>95 \%$ of affected patients are sporadic cases to date) has been linked to the APOE gene on chromosome 19. ${ }^{90,91}$ Three major alleles have been identified, APOE $\varepsilon 2$, APOE $\varepsilon 3$, and APOE $\varepsilon 4$, with the APOE $\varepsilon 3$ allele being the most common. Individuals homozygous for the $\mathrm{APOE} \varepsilon 4$ allele are more likely to develop sporadic AD or FAD at an earlier age of onset compared with individuals with one (heterozygous) or no copies of the APOE $\varepsilon 4$ allele. ${ }^{92-94}$ In contrast, the presence of the APOE $\varepsilon 2$ allele may decrease the risk for $\mathrm{AD}$ but is associated with a higher risk of hemorrhage due to cerebral amyloid angiopathy. ${ }^{95}$ APOE is a $34-\mathrm{kDa}$ glycoprotein that is synthesized principally in the liver and functions in lipid transport, notably cholesterol, and metabolic pathways. ${ }^{96}$ The brain is also enriched in APOE mRNA and protein, with astrocytes being the primary cell type for protein localization, particularly in the aged brain, ${ }^{91,97}$ although APOE is present in neurons within the human brain. ${ }^{98}$ APOE 
binds to soluble forms of $\mathrm{A} \beta$ peptides in vitro and isoform-specific interactions between APOE and amyloid fibril formation have been demonstrated. ${ }^{99-101}$ APOE also interacts with tau in its nonphosphorylated state in vitro in an isoform-specific manner, with the APOE $\varepsilon 3$ allele binding with a higher affinity to tau than the APOE $\varepsilon 4$ allele. ${ }^{102}$ APOE immunoreactivity has also been localized to SPs and NFTs within the AD brain and other neurodegenerative disorders. ${ }^{98,103,104}$ However, the function of APOE in the normal brain as well as its role in the pathogenesis of $\mathrm{AD}$ is presently unknown. One hypothesis is that APOE, notably the $\varepsilon 4$ allele, may act as a pathological chaperone to increase the deposition, or block the reuptake, of soluble $\mathrm{A} \beta$ peptides and/or hyperphosphorylated tau.

\section{REGIONAL ASSESSMENTS OF GENE EXPRESSION IN THE AD BRAIN}

Newly developed molecular and cellular approaches to neuroscience have enabled the initiation of highthroughput analysis of $\mathrm{AD}$ pathophysiology. To evaluate molecular events associated with the mechanisms of $\mathrm{AD}$ pathogenesis in animal models and human postmortem tissues, microarray studies and other downstream genetic analyses are performed at the regional and cellular levels to characterize transcriptional patterns, or mosaics, that may provide clues into some of the mechanism(s) underlying pathological events. An overriding goal is to apply functional genomics and proteomics-based approaches to neurodegenerative disease research to develop useful biomarkers for eventual pharmacotherapeutic development and disease prevention. At present, the molecular and cellular basis of AD pathogenesis is not well understood. Regional analysis of gene expression is a widely used paradigm because of the relatively large amounts of RNA that can be extracted from carefully dissected frozen animal model tissues as well as postmortem human brain tissues, as evidenced by reports on amyloid overexpression ${ }^{105,106}$ and several neurodegenerative disorders, including AD. ${ }^{107-116}$ An advantage of regional gene expression analysis is that, in most cases, extracted RNA is sufficient to generate significant hybridization signal intensity for microarray analysis, enabling the analysis of thousands of targets without necessitating RNA amplification protocols. However, expression profiles garnered from regional dissections cannot discern molecular signatures in discrete neuronal populations nor can regional assessments evaluate differences in admixed neuronal and nonneuronal populations. Relatively new RNA amplification procedures have been implemented to analyze gene expression profiles of single neurons and homogeneous neuronal populations. ${ }^{117,118} \mathrm{~A}$ decided advantage of single cell and single population gene profiling is that different cell types can be identified and microaspirated based upon their signature neurochemical phenotype. For example, CBF neurons ${ }^{73,119,120}$ and midbrain dopaminergic neurons ${ }^{121-123}$ can be demarcated by selective expression of phenotypic markers and isolated for microdissection, RNA amplification, and subsequent microarray analysis. Additionally, cells that lack a distinct and/or selective phenotype can be analyzed using a variety of histochemical stains, including cresyl violet, hematoxylin and eosin, and thionin ${ }^{124-127}$ for downstream genetic applications. Discrimination of adjacent and admixed cell types enables the differentiation of neuronal subtypes as well as neurons from glia, vascular epithelia, and other nonneuronal cell types within the brain. This type of functional genomics approach is ideal for experiments designed to evaluate potential molecular pathogenetic mechanisms underlying the selective vulnerability of specific neuronal populations affected in $\mathrm{AD}$ and other neurodegenerative disorders.

\section{ACQUISITION OF CELL POPULATIONS FOR FUNCTIONAL GENOMICS}

Alzheimer's disease is hypothesized to present clinically once an undetermined threshold number of critical hippocampal and neocortical neurons lose the ability to perform normative functions and subsequently fail to respond to fluctuations in the external and internal milieu. Degenerating neurons become progressively disconnected from their afferent and efferent projection sites, eventually succumbing to frank neurodegeneration. The brain is a complex structure with heterogeneous neuronal (e.g., pyramidal neurons and interneurons) and nonneuronal cell populations (e.g., glial cells, epithelial cells, inflammatory cells, and vascular elements). Thus, developing a set of molecular and cellular criteria that differentiates vulnerable neurons from those that are not affected during the course of $\mathrm{AD}$ is of tantamount importance. A key factor that determines specificity of sophisticated genetic testing methods is the purity and precise acquisition of identified cells for subsequent microarray and qPCR analysis. Accordingly, single cell and population cell molecular fingerprinting necessitates accurate, nondestructive isolation of cells from optimally prepared tissue sections. ${ }^{18,128,129}$ Two popular and effective microdissection methodologies include laser capture microdissection (LCM) and microaspiration. Laser capture microdissection employs a high-energy laser source that separates desired cells from the remainder of a tissue section and facilitates transfer of the identified cells to a microfuge tube for downstream genetic analysis. ${ }^{130,131}$ Single cells as well as hundreds of cells and other elements can be acquired quickly via LCM. Individual cells and pooled populations of cells can be visualized by immunocytochemical and/or histochemical 
procedures for optimal identification of specific cells of interest for subsequent downstream genetic analyses, including microarray studies and qPCR in animal models of neurodegenerative disorders and postmortem human AD brain tissues. ${ }^{124,125,132,133}$ Microaspiration is another technique used to isolate individual neurons and populations of homogeneous cells. This procedure entails visualizing individual cells or their processes using an inverted microscope workstation connected to a micromanipulator and microcontrolled vacuum source on an air table. Individual cell(s) are patched onto something using a microelectrode and excised. Microaspiration results in accurate dissection of the neurons of interest with minimal disruption of the surrounding neuropil. ${ }^{134-138}$ Microaspiration enables precise dissections of single elements (i.e., individual neurons, neuropil, and dendrites). Single cells can be used alone or pooled with other cells for qPCR and/or RNA amplification and subsequent microarray analysis, including analysis of postmortem $\mathrm{AD}$ tissues. ${ }^{73,119,120,134,135,138}$ Microaspiration provides a more accurate dissection of single cells than LCM but is more labor intensive and has a significantly lower throughput potential. ${ }^{118}$

\section{RNA AMPLIFICATION STRATEGIES}

RNA amplification procedures are now used routinely to amplify input RNA to increase signal detection for microarray analysis and other downstream genetic analyses. RNA amplification methods preserve the original quantitative relationship(s) in an amplified gene population, facilitating downstream quantitative analysis. Amplified antisense RNA (aRNA) amplification, developed by Eberwine and colleagues, ${ }^{139-141}$ utilizes a T7 RNA polymerase-based amplification procedure that allows for quantitation of the relative abundance of gene expression levels. aRNA products maintain a proportional representation of the size and complexity of input mRNAs. ${ }^{139,142}$ aRNA synthesis amplifies genetic signals from limited amounts of fresh, frozen, or fixed tissues and cells and has been used successfully to analyze molecular fingerprints from $\mathrm{AD}$ and control neurons, including mRNAs accessed from SPs and NFT-bearing neurons. ${ }^{134,135,137,143,144}$ Although aRNA is a complicated series of procedures, successful results have been generated with microaspirated animal model and postmortem human brain tissue samples using a wide variety of microarray platforms and several kits that use aRNA technology to amplify small amounts of RNA are available commercially.

A novel technology for RNA-based single-primer isothermal amplification (Ribo-SPIA) yielding high-fidelity RNA amplification for gene expression analysis has been developed and marketed by NuGEN (San Carlos, CA) and is of interest to molecular neuroscientists performing microarray evaluations. ${ }^{145,146}$ Ribo-SPIA isothermal amplification technology is different from methods that use in vitro transcription with a bacteriophage transcription promoter such as T7 polymerase. Ribo-SPIA is a linear RNA amplification procedure that entails the formation of a double-stranded cDNA as a substrate for subsequent single-primer isothermal amplification, effectively generating multiple copies of single-stranded DNA products that are complementary to the initial input mRNA source. ${ }^{147,148}$ A single Ribo-SPIA amplification can generate amplified RNA for multiple hybridization experiments from less than $\sim 5 \mathrm{ng}$ of total RNA. ${ }^{147}$

A new methodology has been developed in our laboratory to amplify RNA from minute amounts of starting material. ${ }^{17,149,150}$ This method, termed terminal continuation (TC) RNA amplification, enables an efficient means of second-strand cDNA synthesis using a twoprimer system. An RNA synthesis promoter is attached to the $3^{\prime}$ and/or $5^{\prime}$ region of cDNA using the TC mechanism. ${ }^{149,150}$ The orientation of amplified RNAs is "antisense," or a novel "sense" orientation, and one round of TC RNA amplification is sufficient for downstream genetic analyses. ${ }^{17,126,149,150}$ Terminal continuation RNA amplification is used for many downstream applications, including gene expression profiling, microarray analysis, and cDNA library/subtraction library construction. Synthesized sense TC-amplified RNA can also be used as a template for in vitro protein translation and proteomic applications. Regional and single cell gene expression studies within the brains of animal models and human postmortem $\mathrm{AD}$, mild cognitive impairment (MCI), and normal control brain tissues have been performed via microarray and qPCR analysis coupled with TC RNA amplification. ${ }^{73,119,120,128,129,132,133,138}$

\section{MICROARRAY PLATFORMS}

Methodological and technical advances have enabled the development of myriad microarray platforms allowing for high-throughput analysis of dozens to hundreds to thousands of genes simultaneously. Microarrays represent miniaturized, high-density dot-blots that take advantage of complementary hybridization between nucleic acids. ${ }^{151-153}$ Synthesis of cDNA microarrays entails adhering cDNAs or expressed sequence-tagged cDNAs (ESTs) to solid supports such as glass slides, plastic slides, or nylon membranes. A parallel technology uses photolithography to adhere oligonucleotides to array media. ${ }^{154}$ The anchored cDNA/EST/oligonucleotide is commonly called the microarray target. Target length varies from short oligonucleotides to chromosomal fragments, depending on the array platform design. Sample RNA is used to generate labeled probes via biotinylated, fluorescent, or radioactive label incorporation. Arrays are washed to remove nonspecific background hybridization 
and imaged using a laser scanner for biotinylated/fluorescently labeled probes and a phosphor imager for radioactively labeled probes. A target-labeled probe complex emits a quantifiable signal that is proportional to the abundance of the labeled probe in the sample. The specific signal intensity (minus background) of total (or amplified) RNA bound to each probe set (e.g., oligonucleotides or cDNAs/ESTs) is expressed as a ratio of the total hybridization signal intensity, reducing variation across array platforms due to differences in specific activity of the probe and absolute quantity of probe present. Quantification of hybridization signal intensity is performed to evaluate relative expression levels of each cDNA, EST, or oligonucleotide located on the array platform. Gene expression is then assessed using statistical and informatics software that enables large volumes of coordinate analyses. Computational analysis is critical due to the large number of data points that are generated from a single assay. ${ }^{155,156} \mathrm{~A}$ prominent caveat of microarray array analysis is that coordinate changes in proteins encoded by the genes of interest are common, but not absolute. ${ }^{157}$

\section{EXPRESSION PROFILE ANALYSIS OF SENILE PLAQUES IN THE AD HIPPOCAMPUS}

Although extensive analysis of the immunocytochemical makeup of SPs has been performed, few data exist on the nonproteinaceous components of these lesions. The presence of RNA species (e.g., mRNA, rRNA, and tRNA) in SPs was evaluated using acridine orange (AO) histofluorescence, alone or in combination with TS staining and immunocytochemistry, in AD brains and related neurodegenerative disorders that display abundant $\mathrm{SPs}^{31,158} \mathrm{AO}$ is a fluorescent dye that intercalates selectively into nucleic acids and has been used to detect RNA and DNA in brain tissues. ${ }^{31,127,138,159}$ Acridine orange can be employed in combination with immunocytochemistry to identify cytoplasmic RNAs and specific antigens of interest (FIG. 2A) and is compatible with confocal microscopy. ${ }^{158,160}$ Quantitative analysis of double-labeled sections demonstrates approximately $55 \%$ of TSstained SPs also contain AO labeling, ${ }^{31,158}$ indicating the presence of RNA species in a significant population of SPs. The observed sequestration of RNA SPs in AD and related disorders prompted single cell analysis of SPs in sections of $\mathrm{AD}$ hippocampus. The expression profile of SPs was compared with individual CA1 neurons and surrounding neuropil of control brains using single cell RNA amplification coupled with custom-designed cDNA arrays. ${ }^{134}$ Results indicate that SPs harbor two distinct populations of gene expression levels. One cluster of transcripts contains high-abundance genes including APP, tau, Bcl-2, bax, protein phosphatase subunits, and several ionotropic glutamate receptors (GluRs). ${ }^{128,134}$ A second grouping of transcripts contains low-abundance genes including neurofilament subunits and glial-enriched mRNAs [e.g., GFAP, interleukin-1 (IL-1), and the receptor for advanced glycation endproducts (AGER)]. ${ }^{128,134} \mathrm{~A}$ molecular fingerprint of SPs obtained from the CA1-subiculum region of $\mathrm{AD}$ brains is presented relative to CA1 neurons in normal brains (FIG. 2D). Additionally, a representation of glial-associated mRNAs enriched in neuropil microaspirated from $\mathrm{AD}$ brains is presented relative to SPs in Figure 2. The presence of mRNA species in extracellular SPs is validated further by combined TS and in situ hybridization histochemistry using a probe against cyclic AMP response element binding protein (CREB) in addition to PCR to identify APP isoforms from individual SPs. ${ }^{134}$ Combined single cell expression profiling, in situ hybridization, and PCR datasets indicate that multiple mRNA species are found in individual, extracellular SPs of the AD hippocampus. Furthermore, expression profiles amplified from SPs are predominantly neuronal. These observations suggest that SPs sequester the remnants of degenerating neurons and their processes. Microglial cells have been identified within SPs and astrocytosis occurs around SPs (FIG. 2), ${ }^{29,31,161}$ but relatively low levels of glial-derived mRNAs are found in SPs, likely reflecting a lower abundance of RNAs in glial cells, ${ }^{162}$ although expression profiling of astrocytes has been performed successfully in animal models. ${ }^{163,164}$

\section{EXPRESSION PROFILE ANALYSIS OF NEUROFIBRILLARY TANGLES IN AD HIPPOCAMPAL CA1 NEURONS}

The pathogenesis of NFTs in AD and related disorders is not well understood and the molecular pathophysiology of these lesions is beginning to be evaluated in animal models of tauopathy and in postmortem human brains. ${ }^{85,86,128,129,135}$ For example, quantitative analysis of hippocampal tissue sections double labeled for AO and TS demonstrates approximately $80 \%$ of TS-positive NFTs are AO-positive. ${ }^{31,158}$ We have employed a single cell microarray analysis scheme to identify transcripts that are differentially regulated in CA1 neurons that bear NFTs in AD relative to non-tangle-bearing CA1 neurons in normal-aged control brains. The underlying hypothesis of this study is that alterations in the expression of specific transcripts will reflect mechanisms underlying the formation of NFTs and their biological consequences in affected neurons. Single cell RNA amplification has been performed in combination with high-density and custom-designed array platforms. Relative to normal CA1 neurons, NFT-bearing neurons in AD displayed significant reductions in several classes of mRNAs implicated in the neuropathology of this disorder, including 

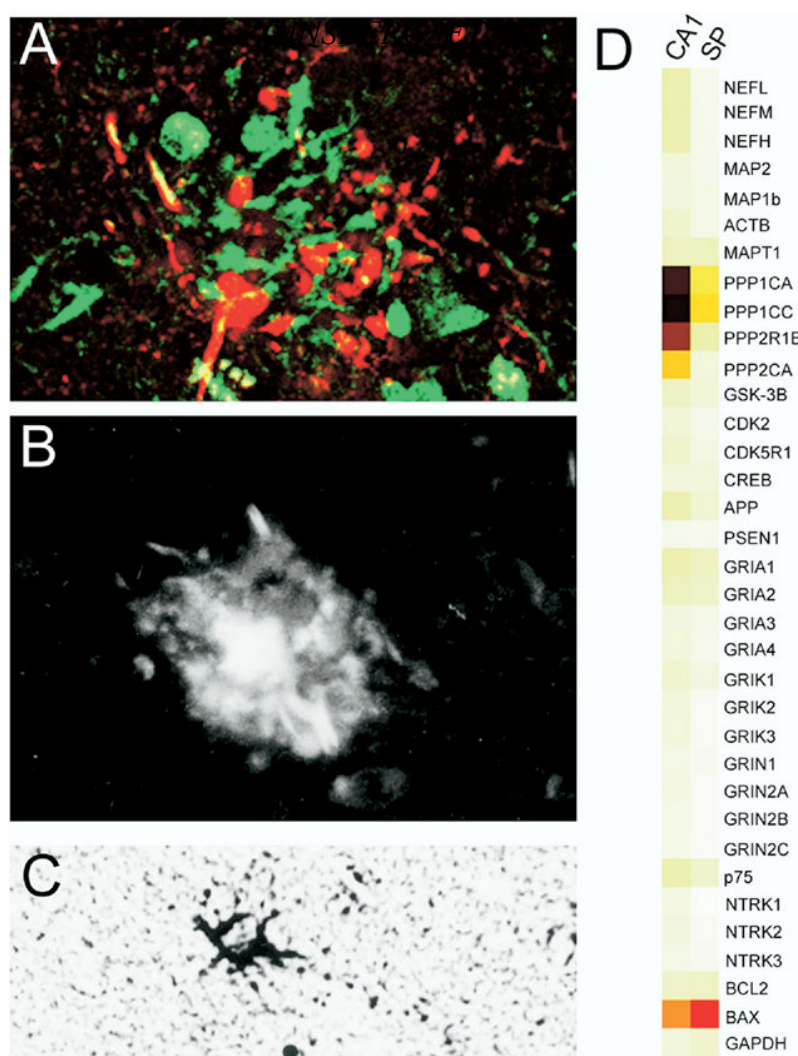

NEFH

AP1b

ACTB

MAPT1

PPP2R1B

K-3B

CDK5R1

CREB

APP

RIA1

RIA 3

GRIA4

GRIK1

RIK 3

GRIN2A

GRIN2B

GRIN2C

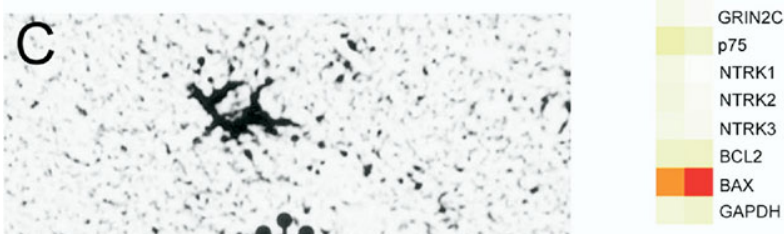

ริ

S
TUBB
APOE
ACT
GFAP
IL-1
IL-6
AGER
TR1A
CFOS
CJUN
SOD1

FIG. 2. Expression profiling within SPs obtained from AD hippocampus. (A) Confocal laser scanning microscopy of an SP labeled by AO histofluorescence and immunocytochemistry against hyperphosphorylated tau. AO is pseudocolored green, while the immunocytochemical labeling is pseudocolored red and the colocalization of the two signals is represented as orange-yellow. Although abundant $\mathrm{AO}$ labeling is present within dystrophic processes of this SP from an AD brain, only occasional colocalization is observed between the $\mathrm{AO}$ signal and PHF1-immunoreactive dystrophic neurites, indicating that the $\mathrm{AO}$ signal is likely originating from amyloid fibrils. (B) Double-label preparations indicating the association between astrocytes and AO-labeled SPs within the entorhinal cortex of an AD patient. B depicts an AO-labeled entorhinal cortex SP. (C) Bright-field photomicrograph of the same section as B, demonstrating the apposition, but not colocalization, of GFAP-immunoreactive astrocytes and AO-labeled SP (asterisk). Scale bar A-C: $25 \mu \mathrm{m}$. (D) Dendrogram illustrating expression profiles garnered from CA1 pyramidal neurons using normal control brains and SPs from AD brains. In addition, a series of glial-associated mRNAs are presented to illustrate the paucity of glial mRNA representation in SPs from AD brains relative to adjacent neuropil (NP) accrued from the CA1-subicular region of AD brain. Note the use of the NCBI-Unigene annotation for Figs. 2D and 3F: ACT, alpha-1-antichymotrypsin; ACTB, beta-actin; AGER, advanced glycosylation end product-specific receptor; APOE, apolipoprotein E; APP, amyloid-beta precursor protein; ARC, activity regulated cytoskeletal-associated protein; BAX, BCL2associated X protein; BCL2, B-cell lymphoma 2; CAMK2, calcium/calmodulin-dependent protein kinase II, alpha; CDK2, cyclindependent kinase 2; CDK5, cyclin-dependent kinase 5; CDK5R1, cyclin-dependent kinase 5, regulatory subunit 1 (p35); DAT, dopamine transporter; DRD1, dopamine receptor 1; DRD2, dopamine receptor 2; DRD3, dopamine receptor 3; DRD4, dopamine receptor 4; DRD5, dopamine receptor 5; cFOS, cellular oncogene fos; cJUN, jun oncogene; CREB, cAMP responsive element binding protein; CTSD, cathepsin D; FAK, focal adhesion kinase; GAPDH, glyceraldehyde-3-phosphate dehydrogenase; GFAP, glial fibrillary acidic protein; GLRX, glutaredoxin; GRIA1, alpha-amino-3-hydroxy-5-methyl-4-isoxazolepropionic acid 1 receptor (AMPA1); GRIA2, AMPA2; GRIA3, AMPA3; GRIA4, AMPA4; GRIK1, kainate receptor 1; GRIK2, kainate 2; GRIK3, kainate 3; GRIN1, N-methyl D-aspartate receptor 1 (NMDAR1); GRIN2A, NMDAR2A; GRIN2B, NMDAR2B; GRIN2C, NMDAR2C; GSK-3B, glycogen synthase kinase-3 beta; HSPG, heparan sulfate proteoglycan; IL-1, interleukin 1; IL-6, interleukin 6; MAP1b; microtubule-associated protein 1b; MAP2, microtubule-associated protein 2; MAPK1, mitogen-activated protein kinase 1 (p44); MAPK2, mitogen-activated protein kinase 2 (p42); MAPT1, three-repeat tau; MAPT2, four-repeat tau; NEFH, neurofilament heavy subunit; NEFL, neurofilament light subunit; NEFM, neurofilament medium subunit; NTRK1, high affinity nerve growth factor receptor trkA; NTRK2, trkB; NTRK3, trkC; p75, low affinity nerve growth factor receptor; PPP1CA, protein phosphatase 1, catalytic subunit, alpha isoform; PPP1CC, protein phosphatase 1, catalytic subunit, gamma isoform; PPP2R1B, protein phosphatase 2, regulatory subunit A, beta isoform; PPP2CA, protein phosphatase 2, catalytic subunit, alpha isoform; PPP2CG, protein phosphatase 2, catalytic subunit, gamma isoform; PSEN1, presenilin 1; PSEN2, presenilin 2; SNCA, alpha-synuclein; SNCB, beta-synuclein; SOD1, superoxide dismutase 1; SYN1, synapsin I; SYP, synaptophysin; SYT1, synaptotagmin I; TR1A, tumor necrosis factor receptor superfamily member $1 \mathrm{~A}$; TUBB, beta-tubulin. 
cytoskeletal elements, dopamine receptors, GluRs, protein phosphatases and kinases, and synaptic-related markers (FIG. 3). ${ }^{118,135}$ Total hybridization signal intensity on the array platform is down-regulated in single $\mathrm{AD}$ NFT-bearing neurons compared with normal CA1 neurons by approximately $30 \%$, consistent with studies of total polyadenylated mRNA expression in AD. ${ }^{165,166} \mathrm{~A}$ correspondence of approximately $85 \%$ between the two array platforms was observed (73/86 cDNAs/ESTs) in terms of the direction (e.g., down-regulation, up-regulation, or no change) of specific genes with dual representation. ${ }^{135}$

As a class of transcripts, mRNAs for protein phosphatase 1 and protein phosphatase 2 subunits displayed significant down-regulation in CA1 neurons with NFTs compared with those without NFTs (FIG. 3B), consistent with related studies implicating reduced protein phosphatase expression and activity as a potential contributing mechanism toward NFT formation. ${ }^{167,168}$ For example, down-regulation of multiple ESTs linked to a single protein phosphatase subunit transcript was observed, including all five ESTs linked to the protein phosphatase 2, regulatory subunit $\mathrm{A}$, beta isoform (PPP2R1B) on the high-density microarray. These observations are consistent with a similar level of relative down-regulation observed on the custom-designed cDNA array platform. ${ }^{128,135}$ Tau hyperphosphorylation in AD and other tauopathies are likely due to dysfunction in protein phosphorylation and dephosphorylation via decreases in protein phosphatase abundance and/or activity, as well as concomitant increases in tau kinases. ${ }^{18,167,169}$ Thus, developing pharmacotherapeutic interventions that ameliorate abnormal tau hyperphosphorylation through protein phosphatase and/or kinase modulation may become a viable and rational therapy for the treatment of disorders with profuse neurofibrillary pathology, including AD and FTDs.

In terms of neurotransmitter systems effected in single neurons, a two- to fourfold decrease in the expression of the mRNAs for dopamine receptors DRD1-DRD5 (NCBI/Unigene annotation) and the dopamine transporter is observed in NFT-bearing neurons in AD versus non-NFT-bearing neurons in control brains (FIG. 3C). ${ }^{135}$ These observations are consistent with results displaying decreased DRD2 receptor binding in the $\mathrm{AD}$ hippocampus. ${ }^{170,171}$ Moreover, single cell results illustrate advantages of employing single cell dopamine receptor mRNA analyses since antibodies and ligandbased studies have not been able to discriminate unequivocally between these dopamine receptor subtypes. In addition, the effects of aging on DRD1-DRD5 mRNA expression levels in hippocampal CA1 pyramidal neurons and entorhinal cortex layer II stellate cells have been evaluated in a cohort of normal control postmortem human brains aged 19-95 years. ${ }^{137}$ Results indicate a significant age-related decline for DRD1-DRD5 mRNAs in CA1 pyramidal neurons with percent decline per decade for each receptor subtype being 5.2, 5.0, 11.2, 4.7, and $5.0 \%$, respectively. ${ }^{137}$ Down-regulation of dopamine receptor subtypes appears to be relatively selective, as no decrement in other mRNAs, including the cytoskeletal elements $\beta$-actin (ACTB), 3Rtau, and 4Rtau, is observed in CA1 pyramidal neurons in the same subjects. ${ }^{137}$ In contrast, no significant changes in dopamine receptor subtype expression are observed in stellate cells across the same cohort. Deficits in dopaminergic neurotransmission contribute to cognitive decline associated with normal aging in the hippocampus of senescent rats and humans ${ }^{172-174}$ and may be relevant toward understanding aspects of the pathophysiology associated with attention and memory deficits in progressive, late-onset neurodegenerative disorders such as $\mathrm{AD}$.

Synaptic loss in $\mathrm{AD}$ is considered one of the hallmarks of the disorder and reduction in gene expression levels of synaptic-related markers is observed consistently in NFT-bearing CA1 neurons, implicating NFTs in synaptic damage to affected neurons. Specifically, synaptic-related markers that are down-regulated include synaptophysin (SYP; 2.2-fold), synaptotagmin I (SYT1; 2.0fold), synapsin I (SYN1; 2.5-fold), $\alpha$-synuclein (SNCA; 2.5 -fold), and $\beta$-synuclein (SNCB; 2.3-fold) (FIG. 3D). ${ }^{128,135}$ These data are consistent with observations that SYP mRNA levels are decreased in the AD hippocampus by qPCR and in situ hybridization. ${ }^{175,176}$ Moreover, selective down-regulation of synaptic-related proteins appears to be an early manifestation of $\mathrm{AD}$, as loss of SYP protein correlates with cognitive decline. ${ }^{177-180}$

Quantitative assessment of high-density cDNA microarrays revealed several ESTs are up-regulated in individual NFT-bearing CA1 pyramidal neurons in $\mathrm{AD}$ brains compared with normal CA1 neurons in agematched control brains, including the lysosomal hydrolase cathepsin D (CatD or CTSD-Unigene abbreviation). ${ }^{128,135}$ CTSD has been demonstrated to be upregulated in endosomal and lysosomal compartments in $\mathrm{AD}$ brain and may have profound pathological sequelae. ${ }^{181-183}$ An approximate twofold up-regulation of CTSD expression is observed on a custom-designed array platform and hyperphosphorylated tau positive NFTs colocalize with increased CTSD immunoreactivity in the same CA1 neurons. ${ }^{3,135}$ Up-regulation of the acid hydrolase CTSD is consistent with a growing body of literature indicating that activation of the endosomallysosomal-autophagic system is a pervasive, early alteration in AD. ${ }^{182,184-186}$ These data illustrate an experimental strategy to employ both high-density and customdesigned microarrays and single cell RNA amplification to identify alterations in the expression levels of numer- 


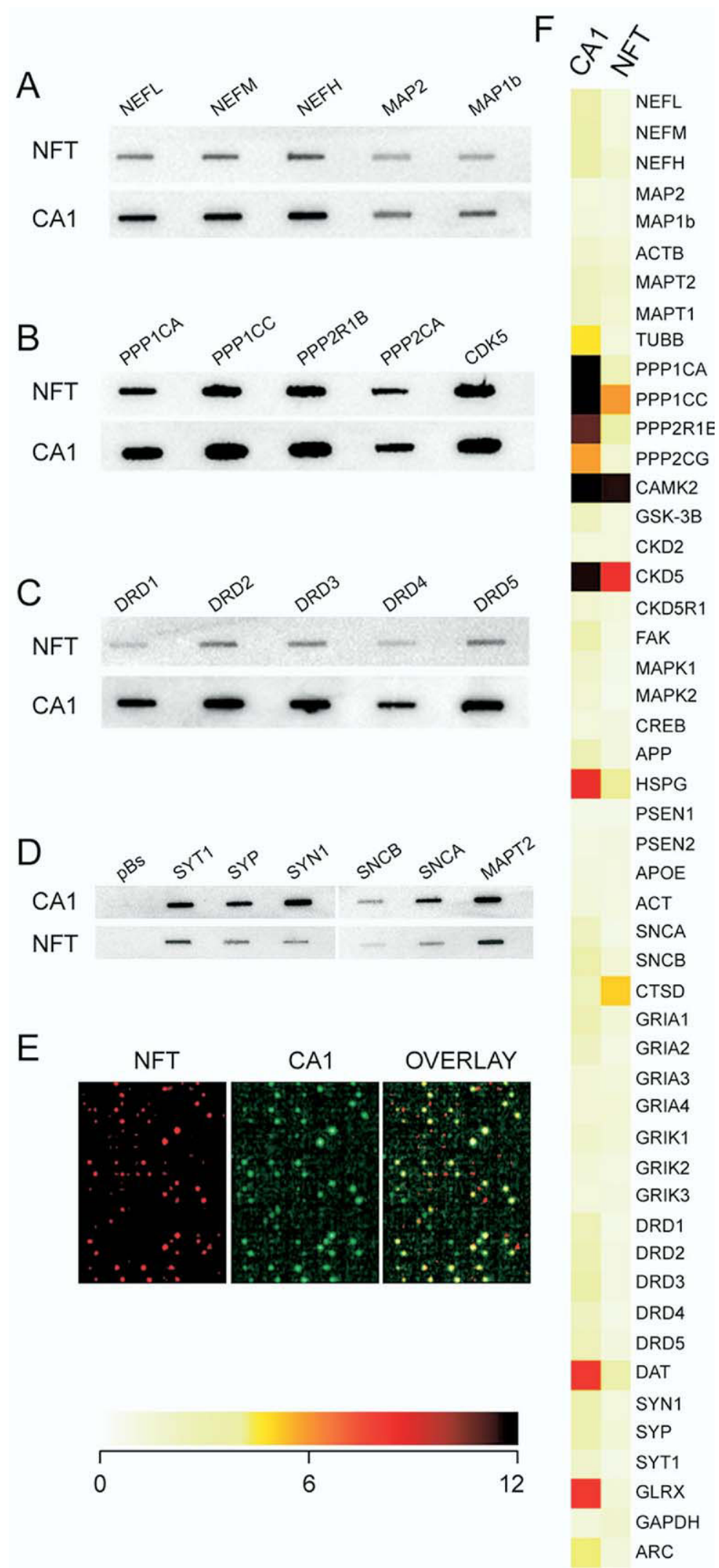


FIG. 3. Expression profile analysis of select transcripts in NFTbearing neurons obtained from $A D$ in comparison with nontangle-bearing neurons from control brains. (A) Down-regulation in the relative abundance of neurofilament gene expression (2- to 4 -fold decrease) in single NFT-bearing neurons. No differences in MAP1b or MAP2 expression were detected. (B) Down-regulation of several protein phosphatase subunits in NFT-bearing neurons. A representative custom cDNA array demonstrates a significant decrease in the relative abundance of mRNAs encoding protein phosphatase 1 subunits (PPP1CA, PPP1CC) and protein phosphatase 2 subunits (PPP2R1B, PPP2CA). (C) Dopamine receptors DRD1-DRD5 are significantly decreased in $A D$ NFT-bearing CA1 neurons compared with nontangle-bearing CA1 pyramidal neurons in control brains. (D) Expression profiling revealed down-regulation of select synaptic-related markers including SNCA, SNCB, SYP, SYN1, and SYT1. In contrast, no differential regulation of 4 Rtau (0 insert; MAPT2) or empty vector (pBs) was observed. (E) A portion of a representative high-density array, illustrating a wide range of hybridization signal using probes generated from NFT-bearing neurons (right; pseudocolored red), normal CA1 neurons (middle; pseudocolored green), and an overlay of NFT-bearing and normal CA1 neuron hybridizations (left). In the left panel, yellow indicates similar hybridization intensities for NFT-bearing neurons and normal CA1 neurons, green indicates a down-regulation in NFT-bearing neurons relative to normal CA1 neurons, and red denotes an up-regulation of an EST within diseased versus normal CA1 neurons. (F) Color-coded dendrogram depicting expression profiles garnered from CA1 pyramidal neurons from normal control brains and NFT-bearing CA1 pyramidal neurons from AD brains.

ous transcripts in AD NFT-bearing neurons compared with normal control CA1 neurons.

\section{SINGLE CELL ANALYSIS OF CBF NEURONS IN AD}

Cholinergic basal forebrain neurons supply the majority of cholinergic fibers to the hippocampal formation and cerebral cortex, are a key component of memory and attention circuits in the brain, ${ }^{187-189}$ are selectively vulnerable in $\mathrm{AD}^{9,190}$ and $\mathrm{CBF}$ neuron degeneration correlates with disease duration and cognitive decline. ${ }^{7,191,192}$ Currently, molecular and cellular mechanisms underlying CBF dysfunction remain unknown. Single cell TC RNA amplification and custom-designed cDNA array technology have been employed to evaluate expression levels of several functional classes of mRNAs found in CBF neurons from normal-aged and AD subjects. ${ }^{6,119,120,138}$ Similar to observations in NFT-bearing CA1 neurons, ${ }^{135}$ down-regulation of synaptic-related markers (e.g., SYP and SYT1) and protein phosphatase 1 and protein phosphatase 2 subunit mRNAs, along with up-regulation of CTSD mRNA, is observed in AD compared with normal control CBF neurons. ${ }^{128,138}$

Attempts to analyze molecular and cellular alterations in specific tau isoforms within vulnerable neuronal populations have been hindered by the lack of antemortem, clinically well-characterized cases. Moreover, select populations of neurons degenerate, whereas others remain intact during the progression of $\mathrm{AD} .{ }^{18,126,129,193,194}$
Cholinergic basal forebrain neurons of the NB display phenotypic alterations in cholinergic markers and contain tau pathology in subjects characterized as MCI. ${ }^{138,195,196}$ Single cell expression profiling was performed to assess the expression levels of the six tau isoforms (MAPT1-MAPT6; FIG. 1) and several other cytoskeletal elements from individual CBF neurons microaspirated using postmortem tissue samples obtained from 34 subjects clinically characterized antemortem with no cognitive impairment (NCI), MCI, and AD. These cases were obtained from the Religious Orders Study, an ongoing longitudinal clinicopathological study of aging and dementia in Catholic nuns, priests, and brothers. ${ }^{6,138,197,198}$ Results indicate that tau transcript expression and other cytoskeletal elements (including neurofilament subunits and tubulin, among others) levels did not differ significantly across groups. However, when the ratios of 3Rtau/4Rtau were calculated, a significant difference in the proportion of 3Rtau/4Rtau mRNA was found in MCI and AD relative to NCI. Specifically, a decrement in the expression ratio of 3Rtau relative to 4Rtau was observed in both $\mathrm{MCI}$ and $\mathrm{AD} \mathrm{CBF}$ neurons in all tau transcripts (e.g., 3Rtau/4Rtau 0 amino terminal insert, 1 amino terminal insert, and 2 amino terminal inserts). ${ }^{73}$ The shift is due to a decrease in 3Rtau as opposed to an increase in 4Rtau levels. In addition, this shift in the 3Rtau/4Rtau ratio was present in NB neurons from $\mathrm{MCI}$ and $\mathrm{AD}$, suggesting that this dysregulation impacts neuronal function and marks a transition from normal cognition to prodromal AD.

Based on these results, a 3Rtau/4Rtau ratio for CA1 pyramidal single cell gene expression profiles from cognitively normal aged controls and end-stage AD cases was calculated. There were no differences in total 3Rtau or 4Rtau expression between microaspirated CA1 neurofilament-immunoreactive from normal aged control brains and hyperphosphorylated tau-immunoreactive NFTs from AD brains. ${ }^{135}$ Similar to the CBF data, there was a shift in the 3Rtau/4Rtau ratio in AD CA1 pyramidal neurons. In contrast to $\mathrm{AD}$, age-related differences within CA1 pyramidal neurons and entorhinal cortex layer II/III stellate cells obtained from a cohort of normal controls aged 19-92 years were not observed in overall tau expression levels or the 3Rtau/4Rtau ratio. ${ }^{73,137}$ The functional significance of a shift in the 3Rtau/4Rtau ratio in vulnerable neurons remains unknown. Studies indicate that 3Rtau and 4Rtau may play different roles in select neurons ${ }^{199,200}$ and could be dysregulated differentially during the pathogenesis of various neurodegenerative diseases. For example, protein expression level studies link alterations in 3Rtau expression to NFT formation in $\mathrm{AD}$, whereas alterations in 4Rtau expression levels are linked to tauopathies such as progressive supranuclear palsy and corticobasal degeneration. ${ }^{81,201-205}$ These data suggest a subtle, yet pervasive change in gene dosage of 

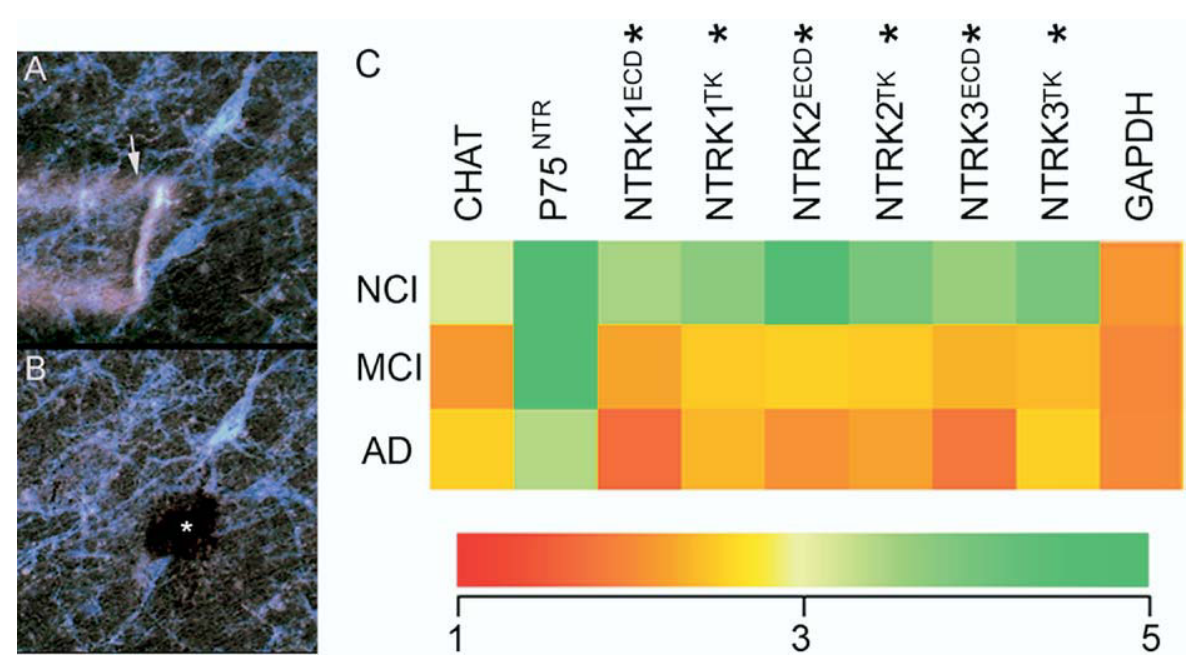

FIG. 4. Expression profiling of individual $\mathrm{CBF}$ neurons in $\mathrm{NCI}, \mathrm{MCl}$, and $\mathrm{AD}$. (A) Dark-field photomicrograph of a representative p75 ${ }^{\mathrm{NTR}}$ -immunoreactive NB neuron before microaspiration. The white arrow points to the tip of a micropipette. (B) Same tissue section shown in A illustrating the site of the microaspirated neuron (white asterisk). (C) Expression profile analysis of p75 ${ }^{\mathrm{NTR}}$, trkA (NTRK1), trkB (NTRK2), trkC (NTRK3), CHAT, and GAPDH derived from individual NB neurons from $\mathrm{NCl}$, $\mathrm{MCl}$, and AD subjects. Dendrogram with a color-coded scale illustrating relative expression levels. No significant differences are found for CHAT, p75 ${ }^{\mathrm{NTR}}$, and GAPDH gene expression. In contrast, down-regulation (asterisk) of trkA, trkB, and trkC are observed in $\mathrm{MCl}$ and AD. ESTs identifying extracellular domain (ECD) and tyrosine kinase (TK) domains display down-regulation. The decrement of trk gene expression in $\mathrm{MCl}$ is intermediate relative to $A D$, indicating a step-down effect in expression levels from $\mathrm{NCl}$ to $\mathrm{MCl}$ to $A D$.

3Rtau and 4Rtau within vulnerable neurons in MCI and $\mathrm{AD}$, which does not occur during normal aging. Shifts in the ratio of tau genes may be a fundamental mechanism whereby normal tau expression is dysregulated, leading to NFT formation.

Degeneration of the CBF system suggests that deficits in cortical cholinergic transmission mediated via NB neurons may contribute to the severe cognitive abnormalities seen in advanced AD. ${ }^{9,206}$ Despite intense interest in the basal forebrain cholinergic cortical projection system, molecular and cellular mechanisms underlying $\mathrm{NB}$ neurodegeneration during the progression of $\mathrm{AD}$ remain unclear. Notably, CBF survival appears to require appropriate binding, internalization, and retrograde transport of the prototypic neurotrophin, NGF, which is synthesized and secreted by cells in the cortex and binds with its high-affinity (trkA) and low-affinity (p75 ${ }^{\mathrm{NTR}}$ ) neurotrophin receptors produced within CBF neurons. ${ }^{206,207}$ Since trkA and $p 75^{\mathrm{NTR}}$ protein levels are reduced within CBF neurons of people with MCI and mild $\mathrm{AD}$, trkA and/or $\mathrm{p} 75^{\mathrm{NTR}}$ gene expression deficits may drive NB degeneration. 6,196

Using single cell expression profiling methods coupled with custom-designed cDNA arrays and validation with real-time qPCR and in situ hybridization, individual cholinergic NB neurons display a significant down-regulation of trkA, trkB, and trkC expression during the progression of $\mathrm{AD} .{ }^{120}$ Specifically, significant down-regulation of trkA, trkB, and trkC is observed in individual neurons microaspirated from $\mathrm{AD}$ and $\mathrm{MCI}$ compared with NCI. ${ }^{120}$ An intermediate reduction is observed in MCI, with the greatest decrement in mild $\mathrm{AD}$ compared with controls. Moreover, down-regulation was found for two separate ESTs for each trk gene [e.g., ESTs targeted to the extracellular domain and tyrosine kinase domain]. ${ }^{120}$ In contrast, dysregulation of choline acetyltransferase and glyceraldehyde-3-phosphate dehydrogenase mRNA was not observed across clinical conditions (FIG. 4). Taken together, these findings indicate a relative selectivity in the alteration of high-affinity neurotrophin receptors within single NB neurons during prodromal stages of $\mathrm{AD}$. Importantly, trkA, trkB, and trkC down-regulation is associated with cognitive decline as measured by a Global Cognitive Score (GCS) and the MiniMental State Examination (MMSE). ${ }^{120}$ In contrast, there is a lack of regulation of $\mathrm{p} 75^{\mathrm{NTR}}$ expression and no association between $\mathrm{p} 75^{\mathrm{NTR}}$ expression and cognitive decline. ${ }^{120,208}$ These observations were not facilitated by low GCS or MMSE scores observed in more severe AD cases examined in this study. Rather, these data indicate that virtually all of the MCI and $\mathrm{AD}$ cases display intermediate and lower expression levels, respectively, that contribute to the overall decrement in expression levels. ${ }^{120}$ These results suggest that the onset of neurotrophic dysfunction in CBF neurons occurs during the earliest stages of cognitive decline and that deficits in trk expression are associated with the clinical presentation of the disease. Thus, trk defects may be a molecular marker for the transition from NCI to $\mathrm{MCI}$ and from MCI to frank AD.

\section{CONCLUSION}

Technical and methodological improvements in microaspiration techniques, RNA amplification, microarray analysis, and qPCR have led to an increase in the number 
of studies of single cell gene expression. However, the brain remains a difficult organ to study, in part due to the nuclear, laminar, and cellular heterogeneity of brain regions and cell types. ${ }^{145,146,209,210}$ Unlike an organ that is comprised of one principal cell type, the brain contains a constellation of neuronal and nonneuronal populations of cells. Importantly, creating a molecular fingerprint of single neurons that are selectively vulnerable requires their precise localization within a defined brain region. Therefore, resolution at the level of homogeneous neuronal populations is optimal to create an expression profile for affected cells such as cholinergic NB neurons and CA1 pyramidal neurons. Simultaneous quantitative assessment of multiple transcripts by microaspiration, RNA amplification, and custom-designed cDNA microarray analysis provides a paradigm whereby the genetic signature of anatomically defined cells within a specific brain region can be differentiated from neighboring structures. ${ }^{18,128,129,194}$ This experimental design allows for rigorous quantitative analyses of vulnerable cell types during the progression of clinical impairment. The unprecedented resolution afforded by single cell RNA analysis in combination with microarrays and qPCR-based analyses allows for relative gene expression level comparisons across cell types under different experimental conditions and disease states. A mosaic of gene expression levels in a subpopulation of single neurons may be more informative than patterns derived from whole brain or regional tissue homogenates, as each neuronal subtype is likely to have a unique molecular signature in normal and pathological states. Moreover, analysis of single neurons avoids possible overlap and intermingling of expression profiles. Furthermore, single cell mRNA analysis has the potential for development of novel pharmacotherapeutic agents that target vulnerable gene(s) and gene products within specific cell types, although high-throughput screening assays using single cells or populations of homogeneous cells in vivo are technologies that will require additional methodological and miniaturization development.

Acknowledgments: Support for this project comes from National Institutes of Health Grants NS43939, NS48447, AG14449, AG10161, AG10688, AG09466, AG17617, and AG26032, and the Alzheimer's Association. We thank I. Elarova, S. Fang, M.D. Ruben, and N. Mohammad for expert technical assistance. We express our appreciation to the families of the patients studied and to the altruism and support of the hundreds of nuns, priests, and brothers participating in the Religious Orders Study. A list of participating groups can be found at the website: http://www.rush.edu/rumc/pageR12394.html.

\section{REFERENCES}

1. Evans DA, Funkenstein HH, Albert MS, Scherr PA, Cook NR, Chown MJ, et al. Prevalence of Alzheimer's disease in a com- munity population of older persons: higher than previously reported. JAMA 262:2256-2551, 1989.

2. Hebert LE, Beckett LA, Scherr PA, Evans DA. Annual incidence of Alzheimer's disease in the United States projected to the years 2000 through 2050. Alzheimer Dis Assoc Disord 15:169-173, 2001.

3. Ginsberg SD, Schmidt ML, Crino PB, Eberwine JH, Lee VM-Y, Trojanowski JQ. Molecular pathology of Alzheimer's disease and related disorders. In: Cerebral cortex: neurodegenerative and agerelated changes in structure and function of cerebral cortex $(\mathrm{Pe}$ ters A, Morrison JH, eds), Vol 14, pp 203-653. New York: Kluwer Academic/Plenum, 1999.

4. Selkoe DJ. Alzheimer's disease: genotypes, phenotypes, and treatments. Science 275:630-631, 1997.

5. Trojanowski JQ, Lee VM. The Alzheimer's brain: finding out what's broken tells us how to fix it. Am J Pathol 167:1183-1188, 2005.

6. Mufson EJ, Counts SE, Fahnestock M, Ginsberg SD. NGF family of neurotrophins and their receptors: early involvement in the progression of Alzheimer's disease. In Neurobiology of Alzheimer's disease 3rd ed. (Dawbarn D, Allen SJ, eds), Oxford, UK: Oxford University Press, 2006.

7. Mufson EJ, Bothwell M, Kordower JH. Loss of nerve growth factor receptor-containing neurons in Alzheimer's disease: a quantitative analysis across subregions of the basal forebrain. Exp Neurol 105:221-232, 1989.

8. Mufson EJ, Bothwell M, Hersh LB, Kordower JH. Nerve growth factor receptor immunoreactive profiles in the normal, aged human basal forebrain: colocalization with cholinergic neurons. J Comp Neurol 285:196-217, 1989.

9. Whitehouse PJ, Price DL, Struble RG, Clark AW, Coyle JT, Delong MR. Alzheimer's disease and senile dementia: loss of neurons in the basal forebrain. Science 215:1237-1239, 1982.

10. Davies P, Maloney AJ. Selective loss of central cholinergic neurons in Alzheimer's disease. Lancet 2:1403, 1976.

11. Hyman BT, van Hoesen GW, Damasio AR, Barnes CL. Alzheimer's disease: cell-specific pathology isolates the hippocampal formation. Science 225:1168-1170, 1984.

12. Hyman BT, van Hoesen GW, Damasio AR. Memory-related neural systems in Alzheimer's disease: an anatomic study. Neurology 40:1721-1730, 1990.

13. Hof PR, Morrison JH. The aging brain: morphomolecular senescence of cortical circuits. Trends Neurosci 27:607-613, 2004.

14. Hyman BT, Trojanowski JQ. Consensus recommendations for the postmortem diagnosis of Alzheimer's disease from the National Institute on Aging and the Reagan Institute Working Group on diagnostic criteria for the neuropathological assessment of Alzheimer's disease. J Neuropathol Exp Neurol 56:1095-1097, 1997.

15. Mirra SS, Heyman A, McKeel D, Sumi SM, Crain BJ, Brownlee LM, et al. The Consortium to Establish a Registry for Alzheimer's Disease (CERAD): Part II. Standardization of the neuropathologic assessment of Alzheimer's disease. Neurology 41: 479-486, 1991.

16. Berchtold NC, Cotman CW. Evolution in the conceptualization of dementia and Alzheimer's disease: Greco-Roman period to the 1960s. Neurobiol Aging 19:173-189, 1998.

17. Alzheimer A. Uber eine eigenartige Erkrangkung der Hirnrinde. All Z Psychiatr 64:146-148, 1907.

18. Skovronsky DM, Lee VM-Y, Trojanowski JQ. Neurodegenerative diseases: new concepts of pathogenesis and their therapeutic implications. Annu Rev Pathol Mech Dis 1:151-170, 2006.

19. Cohen AS, Connors LH. The pathogenesis and biochemistry of amyloidosis. J Pathol 151:1-10, 1987.

20. Iwai A, Yoshimoto M, Masliah E, Saitoh T. Non-A $\beta$ component of Alzheimer's disease amyloid (NAC) is amyloidogenic. Biochemistry 34:10139-10145, 1995.

21. Masliah E, Iwai A, Mallory M, Ueda K, Saitoh T. Altered presynaptic protein NACP is associated with plaque formation and neurodegeneration in Alzheimer's disease. Am J Pathol 148:201210, 1996.

22. Schmidt ML, DiDario AG, Otvos L Jr, Hoshi M, Kant JA, Lee VM-Y, et al. Plaque-associated neuronal proteins: a recurrent 
motif in neuritic amyloid deposits throughout diverse cortical areas of the Alzheimer's disease brain. Exp Neurol 130:311-322, 1994.

23. Pasinetti GM. Inflammatory mechanisms in neurodegeneration and Alzheimer's disease: the role of the complement system. Neurobiol Aging 17:707-716, 1996.

24. Atwood CS, Martins RN, Smith MA, Perry G. Senile plaque composition and posttranslational modification of amyloid- $\beta$ peptide and associated proteins. Peptides 23:1343-1350, 2002.

25. Glenner GG, Wong CW. Alzheimer's disease: initial report of the purification and characterization of a novel cerebrovascular amyloid protein. Biochem Biophys Res Commun 120:885-890, 1984.

26. Masters CL, Simms G, Weinman NA, Multhaup G, McDonald BL, Beyreuther K. Amyloid plaque core protein in Alzheimer's disease and Down syndrome. Proc Natl Acad Sci USA 82:42454249, 1985.

27. Perlmutter LS, Barron E, Chui HC. Morphologic association between microglia and senile plaque amyloid in Alzheimer's disease. Neurosci Lett 119:32-36, 1990.

28. Dickson DW, Lee SC, Mattiace LA, Yen S-HC, Brosnan CF. Microglia and cytokines in neurological disease, with special reference to AIDS and Alzheimer's disease. Glia 7:75-83, 1993.

29. Itagaki S, McGeer PL, Akiyama H, Zhu S, Selkoe D. Relationship of microglia and astrocytes to amyloid deposits of Alzheimer's disease. J Neuroimmunol 24:173-182, 1989.

30. Vehmas AK, Kawas CH, Stewart WF, Troncoso JC. Immune reactive cells in senile plaques and cognitive decline in Alzheimer's disease. Neurobiol Aging 24:321-331, 2003.

31. Ginsberg SD, Crino PB, Lee VM-Y, Eberwine JH, Trojanowski JQ. Sequestration of RNA in Alzheimer's disease neurofibrillary tangles and senile plaques. Ann Neurol 41:200-209, 1997.

32. Iwatsubo T, Saido TC, Mann DMA, Lee VM-Y, Trojanowski JQ. Full-length amyloid- $\beta(1-42(43))$ and amino-terminally modified and truncated amyloid $\beta 42(43)$ deposit in diffuse plaques. Am J Pathol 149:1823-1830, 1996.

33. Masliah E, Terry RD, Mallory N, Alford M, Hansen LA. Diffuse plaques do not accentuate synapse loss in Alzheimer's disease. Am J Pathol 137:1293-1297, 1990.

34. Mufson EJ, Chen EY, Cochran EJ, Beckett LA, Bennett DA, Kordower JH. Entorhinal cortex $\beta$-amyloid load in individuals with mild cognitive impairment. Exp Neurol 158:469-490, 1999.

35. Giannakopoulos P, Herrmann FR, Bussiere T, Bouras C, Kovari E, Perl DP, et al. Tangle and neuron numbers, but not amyloid load, predict cognitive status in Alzheimer's disease. Neurology 60:1495-1500, 2003.

36. Bussiere T, Friend PD, Sadeghi N Wicinski B Lin Gl, Bouras C, et al. Stereologic assessment of the total cortical volume occupied by amyloid deposits and its relationship with cognitive status in aging and Alzheimer's disease. Neuroscience 112:75-91, 2002.

37. Billings LM, Oddo S, Green KN, McGaugh JL, LaFerla FM. Intraneuronal $\mathrm{A} \beta$ causes the onset of early Alzheimer's diseaserelated cognitive deficits in transgenic mice. Neuron 45:675-688, 2005.

38. Takahashi RH, Milner TA, Li F, Nam EE, Edgar MA, Yamaguchi $\mathrm{H}$, et al. Intraneuronal Alzheimer $\mathrm{A}\{\beta\} 42$ accumulates in multivesicular bodies and is associated with synaptic pathology. Am J Pathol 161:1869-1879, 2002.

39. Yang AJ, Knauer M, Burdick DA, Glabe C. Intracellular A $\beta$ 1-42 aggregates stimulate the accumulation of stable, insoluble amyloidogenic fragments of the amyloid precursor protein in transfected cells. J Biol Chem 270:14786-14792, 1995.

40. Casas C, Sergeant N, Itier JM, Blanchard V, Wirths O, van der Kolk N, et al. Massive CA1/2 neuronal loss with intraneuronal and N-terminal truncated $A \beta 42$ accumulation in a novel Alzheimer transgenic model. Am J Pathol 165:1289-1300, 2004.

41. Leverenz JB, Raskind MA. Early amyloid deposition in the medial temporal lobe of young Down syndrome patients: a regional quantitative analysis. Exp Neurol 150:296-304, 1998.

42. Hirayama A, Horikoshi Y, Maeda M, Ito M, Takashima S. Characteristic developmental expression of amyloid $\beta 40,42$ and 43 in patients with Down syndrome. Brain Dev 25:180-185, 2003.

43. Rovelet-Lecrux A, Hannequin D, Raux G, Meur NL, Laquerriere A, Vital A, et al. APP locus duplication causes autosomal dom- inant early-onset Alzheimer's disease with cerebral amyloid angiopathy. Nat Genet 38:24-26, 2006.

44. Selkoe DJ. Amyloid- $\beta$-protein and the genetics of Alzheimer's disease. J Biol Chem 271:18295-18298, 1996.

45. Goate A, Chartier-Harlin MC, Mullan M, Brown J, Crawford F, Fidani L, et al. Segregation of a missense mutation in the amyloid precursor protein gene with familial Alzheimer's disease. Nature 349:704-706, 1991.

46. Borchelt DR, Thinakaran G, Eckman CB, Lee MK, Davenport F, Ratovitsky T, et al. Familial Alzheimer's disease-linked presenilin 1 variants elevate $\mathrm{A} \beta 1-42 / 40$ ratio in vitro and in vivo. Neuron 17:1005-1013, 1996.

47. Games D, Adams D, Alessandrini R, Barbour R, Berthelette P, Blackwell C, et al. Alzheimer-type neuropathology in transgenic mice overexpressing V717F $\beta$-amyloid precursor protein. Nature 373:523-527, 1995.

48. Hsiao K, Chapman P, Nilsen S, Eckman C, Harigaya Y, Younkin $\mathrm{S}$, et al. Correlative memory deficits, $A \beta$ elevation, and amyloid plaques in transgenic mice. Science 274:99-102, 1996.

49. Finckh U, Kuschel C, Anagnostouli M, Patsouris E, Pantes GV, Gatzonis S, et al. Novel mutations and repeated findings of mutations in familial Alzheimer's disease. Neurogenetics 6:85-89, 2005.

50. Rogaev EI, Sherrington R, Rogaeva EA, Levesque G, Ikeda M, Liang Y, et al. Familial Alzheimer's disease in kindreds with missense mutations in a gene on chromosome 1 related to the Alzheimer's disease type 3 gene. Nature 376:775-778, 1995.

51. Sherrington R, Rogaev EI, Liang Y, Rogaeva EA, Levesque G, Ikeda M, et al. Cloning of a gene bearing missense mutations in early-onset familial Alzheimer's disease. Nature 375:754-760, 1995.

52. Kovacs DM, Fausett HJ, Page KJ, Kim T-W, Moir RD, Merriam $\mathrm{DE}$, et al. Alzheimer-associated presenilins 1 and 2: neuronal expression in brain and localization to intracellular membranes in mammalian cells. Nat Med 2:224-229, 1996

53. Lah JJ, Heilman CJ, Nash NR, Rees HD, Yi H, Counts SE, et al. Light and electron microscopic localization of presenilin-1 in primate brain. J Neurosci 17:1971-1980, 1997.

54. Iwatsubo T. The gamma-secretase complex: machinery for intramembrane proteolysis. Curr Opin Neurobiol 14:379-383, 2004.

55. Pasternak SH, Bagshaw RD, Guiral M, Zhang S, Ackerley CA, Pak BJ, et al. Presenilin-1, nicastrin, amyloid precursor protein, and gamma-secretase activity are co-localized in the lysosomal membrane. J Biol Chem 278:26687-26894, 2003.

56. Duff K, Eckman C, Zehr C, Yu X, Prada C-M, Perez-tur J, et al. Increased amyloid- $\beta 42(43)$ in brains of mice expressing mutant presenilin 1. Nature 383:710-713, 1996.

57. Citron M, Westaway D, Xia W, Carlson G, Levesque G, JohnsonWood K, et al. Mutant presenilins of Alzheimer's disease increase production of 42-residue amyloid $\beta$-protein in both transfected cells and transgenic mice. Nat Med 3:67-72, 1997.

58. Iwatsubo T, Okada A, Suzuki N, Mizusawa N, Nukina N, Ihara Y. Visualization of $A \beta 42(43)$ and $A \beta 40$ in senile plaques with end-specific $\mathrm{A} \beta$ monoclonals: evidence that an initially deposited species is A $\beta 42(43)$. Neuron 13:45-53, 1994.

59. Jarrett JT, Berger EP, Lansbury PT Jr. The carboxy terminus of the beta amyloid protein is critical for the seeding of amyloid formation: implications for the pathogenesis of Alzheimer's disease. Biochemistry 32:4693-4697, 1993.

60. Jin L-W, Maezawa I, Vincent I, Bird T. Intracellular accumulation of amyloidogenic fragments of amyloid- $\{\beta\}$ precursor protein in neurons with Niemann-Pick Type $C$ defects is associated with endosomal abnormalities. Am J Pathol 164:975-985, 2004.

61. Hauser ER, Pericak-Vance MA. Genetic analysis for common complex disease. Am Heart J 140:S36-S44, 2000.

62. Bently DR, Dunham I. Mapping human chromosomes. Curr Opin Genet Dev 5:328-334, 1995.

63. Pericak-Vance MA, Grubber J, Bailey LR, Hedges D, West S, Santoro L, et al. Identification of novel genes in late-onset Alzheimer's disease. Exp Gerontol 35:1343-1352, 2000.

64. Olson JM, Goddard KA, Dudek DM. A second locus for verylate-onset Alzheimer's disease: a genome scan reveals linkage to 
$20 \mathrm{p}$ and epistasis between $20 \mathrm{p}$ and the amyloid precursor protein region. Am J Hum Genet 71:154-161, 2002.

65. Grupe A, Li Y, Rowland C, Nowotny P, Hinrichs AL, Smemo S, et al. A scan of chromosome 10 identifies a novel locus showing strong association with late-onset Alzheimer's disease. Am J Hum Genet 78:78-88. 2006.

66. Schmitz C, Rutten BPF, Pielen A, Schafer S, Wirths O, Tremp G et al. Hippocampal neuron loss exceeds amyloid plaque load in a transgenic mouse model of Alzheimer's disease. Am J Pathol 164:1495-1502, 2004.

67. Couchie D, Mavilia C, Georgieff IS, Liem RK, Shelanski ML, Nunez J. Primary structure of high molecular weight tau present in the peripheral nervous system. Proc Natl Acad Sci USA 89: 4378-4381, 1992.

68. Binder LI, Frankfurter A, Rebhun LI. The distribution of tau in the mammalian central nervous system. J Cell Biol 101:1371$1378,1985$.

69. Goedert M, Jakes R. Mutations causing neurodegenerative tauopathies. Biochim Biophys Acta 1739:240-250, 2005.

70. Goedert M, Spillantini MG, Potier MC, Ulrich J, Crowther RA. Cloning and sequencing of the cDNA encoding an isoform of microtubule-associated protein tau containing four tandem repeats: differential expression of tau protein mRNAs in human brain. EMBO J 8:393-399, 1989.

71. Goedert M, Spillantini MG, Jakes R, Rutherford D, Crowther RA. Multiple isoforms of human microtubule-associated protein tau: sequences and localization in neurofibrillary tangles of Alzheimer's disease. Neuron 3:519-526, 1989.

72. Goode BL, Feinstein SC. Identification of a novel microtubule binding and assembly domain in the developmentally regulated inter-repeat region of tau. J Cell Biol 124:769-782, 1994.

73. Ginsberg SD, Che S, Counts SE, Mufson EJ. Shift in the ratio of three-repeat tau and four-repeat tau mRNAs in individual cholinergic basal forebrain neurons in mild cognitive impairment and Alzheimer's disease. J Neurochem 96:1401-1408, 2006.

74. Drecshel, DN, Hyman AA, Cobb MH, Kirschner M. Modulation of the dynamic instability of tubulin assembly by the microtubule associated protein tau. Mol Biol Cell 3:1147-1154, 1992.

75. Kosik KS, Shimura H. Phosphorylated tau and the neurodegenerative foldopathies. Biochim Biophys Acta 1739:298-310, 2005.

76. Morishima-Kawashima M, Hasegawa M, Takio K, Suzuki M, Yoshida H, Titani K, et al. Proline-directed and non-prolinedirected phosphorylation of PHF-tau. J Biol Chem 270:823-829, 1995.

77. Poorkaj P, Bird TD, Wijsman E, Nemens E, Garruto RM, Anderson $\mathrm{L}$, et al. Tau is a candidate gene for chromosome 17 frontotemporal dementia. Ann Neurol 43:815-825, 1998.

78. Hutton M, Lendon CL Rizzu P, Baker M, Froelich S, Houlden H, et al. Association of missense and $5^{\prime}$-splice-site mutations in tau with the inherited dementia FTDP-17. Nature 393:702-705, 1998.

79. Lee VM, Goedert M, Trojanowski JQ. Neurodegenerative tauopathies. Annu Rev Neurosci 24:1121-1159, 2001.

80. Ingram EM, Spillantini MG. Tau gene mutations: dissecting the pathogenesis of FTDP-17. Trends Mol Med 8:555-562, 2002.

81. Mott RT, Dickson DW, Trojanowski JQ, Zhukareva V, Lee VM, Forman M, et al. Neuropathologic, biochemical, and molecular characterization of the frontotemporal dementias. $J$ Neuropathol Exp Neurol 64:420-428, 2005.

82. Spillantini MG, Bird TD, Ghetti B. Frontotemporal dementia and Parkinsonism linked to chromosome 17: a new group of tauopathies. Brain Pathol 8:387-402, 1998.

83. Bergmann M, Kuchelmeister K, Schmid KW, Kretzschmar HA, Schroder R. Different variants of frontotemporal dementia: a neuropathological and immunohistochemical study. Acta Neuropathol (Berl) 92:170-179, 1996.

84. Hong M, Zhukareva V, Vogelsberg-Ragaglia V, Wszolek Z, Reed $\mathrm{L}$, Miller BI, et al. Mutation-specific functional impairments in distinct tau isoforms of hereditary FTDP-17. Science 282:19141917, 1998.

85. Andorfer C, Kress Y, Espinoza M, de Silva R, Tucker KL, Barde $\mathrm{Y}-\mathrm{A}$, et al. Hyperphosphorylation and aggregation of tau in mice expressing normal human tau isoforms. $J$ Neurochem 86:582-590, 2003.

86. Andorfer C, Acker CM, Kress Y, Hof PR, Duff K, Davies P. Cell-cycle reentry and cell death in transgenic mice expressing nonmutant human tau isoforms. J Neurosci 25:5446-5454, 2005.

87. Gotz J, Chen F, Barmettler R, Nitsch RM. Tau filament formation in transgenic mice expressing P301L tau. J Biol Chem 276:529534, 2001.

88. Ramsden M, Kotilinek L, Forster C, Paulson J, McGowan E, SantaCruz K, et al. Age-dependent neurofibrillary tangle formation, neuron loss, and memory impairment in a mouse model of human tauopathy (P301L). J Neurosci 25:10637-10647, 2005.

89. Ikeda M, Shoji M, Kawarai T, Kawarabayashi T, Matsubara E, Murakami T, et al. Accumulation of filamentous tau in the cerebral cortex of human tau R406W transgenic mice. Am J Pathol 166:521-531, 2005.

90. Poirier J. Apolipoprotein E, cholesterol transport and synthesis in sporadic Alzheimer's disease. Neurobiol Aging 26:355-361, 2005.

91. Strittmatter WJ, Roses AD. Apolipoprotein E and Alzheimer disease. Proc Natl Acad Sci USA 92:4725-4727, 1995.

92. Blacker D, Haines JL, Rodes L, Terwedow H, Go RC, Harrell LE, et al. ApoE-4 and age at onset of Alzheimer's disease: the NIMH genetics initiative. Neurology 48:139-147, 1997.

93. Bennett DA, Wilson RS, Schneider JA, Evans DA, Aggarwal NT, Arnold SE, et al. Apolipoprotein E $\varepsilon 4$ allele, AD pathology, and the clinical expression of Alzheimer's disease. Neurology 60: 246-252, 2003.

94. Corder EH, Saunders AM, Strittmatter WJ, Schmechel DE, Gaskell PC, Small GW, et al. Gene dose of apolipoprotein E type 4 allele and the risk of Alzheimer's disease in late onset families. Science 261:921-923, 1993.

95. Corder EH, Saunders AM, Risch NJ, Strittmatter WJ, Schmechel DE, Gaskell PC Jr, et al. Protective effect of apolipoprotein E type 2 allele for late onset Alzheimer's disease. Nat Genet 7:180 184, 1994.

96. Mahley RW. Apolipoprotein E: cholesterol transport protein with expanding role in cell biology. Science 240:622-630, 1988.

97. Lahiri DK. Apolipoprotein E as a target for developing new therapeutics for Alzheimer's disease based on studies from protein, RNA, and regulatory region of the gene. $J$ Mol Neurosci 23:225-233, 2004.

98. Benzing WC, Mufson EJ. Apolipoprotein E immunoreactivity within neurofibrillary tangles: relationship to tau and PHF in Alzheimer's disease. Exp Neurol 132:162-171, 1995.

99. Strittmatter WJ, Weisgraber KH, Huang DY, Dong L-M, Salvesen GS, Pericak-Vance M, et al. Binding of human apolipoprotein $\mathrm{E}$ to synthetic amyloid $\beta$ peptide: isoform-specific effects and implications for late-onset Alzheimer's disease. Proc Natl Acad Sci USA 90:8098-8102, 1993.

100. Wisniewski T, Castano EM, Golabek A, Vogel T, Frangione B. Acceleration of Alzheimer's fibril formation by apolipoprotein E in vitro. Am J Pathol 145:1030-1035, 1994.

101. Sanan DA, Weisgraber K, Russell SJ, Mahley RW, Huang D, Saunders A, et al. Apolipoprotein E associates with $\mathrm{A} \beta$ amyloid peptide to form novel monofibrils: isoform apoE4 associates more efficiently than apoE3. J Clin Invest 94:860-869, 1994.

102. Strittmatter WJ, Saunders AM, Goedert M, Weisgraber KH, Dong L-M, Jakes R, et al. Isoform-specific interactions of apolipoprotein $\mathrm{E}$ with microtubule-associated protein tau: implications for Alzheimer's disease. Proc Natl Acad Sci USA 91:1118311186, 1994.

103. Namba Y, Tomonaga M, Kawasaki H, Otomo E, Ikeda K. Apolipoprotein $\mathrm{E}$ immunoreactivity in cerebral amyloid deposits and neurofibrillary tangles in Alzheimer's disease and kuru plaque amyloid in Creutzfeldt-Jakob disease. Brain Res 541:163-166, 1991.

104. Bao F, Arai H, Matsushita S, Higuchi S, Sasaki H. Expression of apolipoprotein $\mathrm{E}$ in normal and diverse neurodegenerative disease brain. NeuroReport 7:1733-1739, 1996.

105. Dickey CA, Loring JF, Montgomery J, Gordon MN, Eastman PN, Morgan D. Selectively reduced expression of synaptic plasticity- 
related genes in amyloid precursor protein + presenilin-1 transgenic mice. J Neurosci 23:5219-5226, 2003.

106. Reddy PH, McWeeney S, Park BS, Manczak M, Gutala RV, Partovi D, et al. Gene expression profiles of transcripts in amyloid precursor protein transgenic mice: up-regulation of mitochondrial metabolism and apoptotic genes is an early cellular change in Alzheimer's disease. Hum Mol Genet 13:1225-1240, 2004.

107. Blalock EM, Geddes JW, Chen KC, Porter NM, Markesbery WR, Landfield PW. Incipient Alzheimer's disease: microarray correlation analyses reveal major transcriptional and tumor suppressor responses. Proc Natl Acad Sci USA 101:2173-2178, 2004.

108. Colangelo V, Schurr J, Ball MJ, Pelaez RP, Bazan NG, Lukiw WJ. Gene expression profiling of 12633 genes in Alzheimer hippocampal CA1: transcription and neurotrophic factor downregulation and up-regulation of apoptotic and pro-inflammatory signaling. J Neurosci Res 70:462-473, 2002.

109. Loring JF, Wen X, Lee JM, Seilhamer J, Somogyi R. A gene expression profile of Alzheimer's disease. DNA Cell Biol 20:683695,2001

110. Lukiw WJ. Gene expression profiling in fetal, aged, and Alzheimer hippocampus: a continuum of stress-related signaling. $\mathrm{Neu}$ rochem Res 29:1287-1297, 2004.

111. Minagar A, Shapshak P, Duran EM, Kablingerm AS, Alexander JS, Kelley RE, et al. HIV-associated dementia, Alzheimer's disease, multiple sclerosis, and schizophrenia: gene expression review. J Neurol Sci 224:3-17, 2004.

112. Roy Walker P, Smith B, Liu QY Fazel Famili A, Valdes JJ, Liu $\mathrm{Z}$, et al. Data mining of gene expression changes in Alzheimer brain. Artif Intell Med 31:137-154, 2004.

113. Katsel PL, Davis KL, Haroutunian V. Large-scale microarray studies of gene expression in multiple regions of the brain in schizophrenia and Alzheimer's disease. Int Rev Neurobiol 63:4182, 2005.

114. Marcotte ER, Srivastava LK, Quirion R. cDNA microarray and proteomic approaches in the study of brain diseases: focus on schizophrenia and Alzheimer's disease. Pharmacol Ther 100:6374, 2003.

115. Ricciarelli R, d'Abramo C, Massone S, Marinari U, Pronzato M, Tabaton M. Microarray analysis in Alzheimer's disease and normal aging. IUBMB Life 56:349-354, 2004.

116. Blalock EM, Chen KC, Stromberg AJ, Norris CM, Kadish I, Kraner SD, et al. Harnessing the power of gene microarrays for the study of brain aging and Alzheimer's disease: statistical reliability and functional correlation. Aging Res Rev 4:481-512, 2005.

117. Ginsberg SD. RNA amplification strategies for small sample populations. Methods 37:229-237, 2005.

118. Ginsberg SD, Hemby SE, Mufson EJ, Martin LJ. Cell and tissue microdissection in combination with genomic and proteomic applications. In: Neuroanatomical tract tracing 3: Molecules-neurons-systems (Zaborszky L, Wouterlood F, Lanciego JL, eds), pp 109-141. New York: Springer/Kluwer/Plenum, 2006.

119. Counts SE, Chen EY, Che S, Ikonomovic MD, Wuu J, Ginsberg $\mathrm{SD}$, et al. Galanin fiber hypertrophy within the cholinergic nucleus basalis during the progression of Alzheimer's disease. Dement Geriatr Cogn Disord 21:205-214, 2006.

120. Ginsberg SD, Che S, Wuu J, Counts SE, Mufson EJ. Down regulation of trk but not p75NTR gene expression in single cholinergic basal forebrain neurons mark the progression of Alzheimer's disease. J Neurochem 97:475-487, 2006.

121. Fasulo WH, Hemby SE. Time-dependent changes in gene expression profiles of midbrain dopamine neurons following haloperidol administration. J Neurochem 87:205-219, 2003.

122. Tang WX, Fasulo WH, Mash DC, Hemby SE. Molecular profiling of midbrain dopamine regions in cocaine overdose victims. J Neurochem 85:911-924, 2003.

123. Greene JG, Dingledine R, Greenamyre JT. Gene expression profiling of rat midbrain dopamine neurons: implications for selective vulnerability in parkinsonism. Neurobiol Dis 18:19-31, 2005.

124. Kamme F, Salunga R, Yu J, Tran DT, Zhu J, Luo L, et al. Single-cell microarray analysis in hippocampus CA1: demonstra- tion and validation of cellular heterogeneity. $J$ Neurosci 23:3607-3615, 2003.

125. Luo L, Salunga RC, Guo H, Bittner A, Joy KC, Galindo JE, et al. Gene expression profiles of laser-captured adjacent neuronal subtypes. Nat Med 5:117-122, 1999.

126. Ginsberg SD, Che S. Combined histochemical staining, RNA amplification, regional, and single cell analysis within the hippocampus. Lab Invest 84:952-962, 2004.

127. Vincent VA, DeVoss JJ, Ryan HS, Murphy GM Jr. Analysis of neuronal gene expression with laser capture microdissection. J Neurosci Res 69:578-586, 2002.

128. Ginsberg SD, Elarova I, Ruben M, Tan F, Counts SE, Eberwine $\mathrm{JH}$, et al. Single cell gene expression analysis: implications for neurodegenerative and neuropsychiatric disorders. Neurochem Res 29:1054-1065, 2004.

129. Ginsberg SD, Che S. Expression profile analysis within the human hippocampus: comparison of CA1 and CA3 pyramidal neurons. J Comp Neurol 487:107-118, 2005.

130. Bonner RF, Emmert-Buck M, Cole K, Pohida T, Chuaqui R, Goldstein S, et al. Laser capture microdissection: molecular analysis of tissue. Science 278:1481-1483, 1997.

131. Emmert-Buck MR, Bonner RF, Smith PD, Chuaqui RF, Zhuang $\mathrm{Z}$, Goldstein SR, et al. Laser capture microdissection. Science 274:998-1001, 1996.

132. Ginsberg SD. Glutamatergic neurotransmission expression profiling in the mouse hippocampus after perforant-path transection. Am J Geriatr Psychiatry 13:1052-1061, 2005.

133. Ginsberg SD, Che S. RNA amplification in brain tissues. Neurochem Res 27:981-992, 2002.

134. Ginsberg SD, Crino PB, Hemby SE, Weingarten JA, Lee VM-Y, Eberwine $\mathrm{JH}$, et al. Predominance of neuronal mRNAs in individual Alzheimer's disease senile plaques. Ann Neurol 45:174$181,1999$.

135. Ginsberg SD, Hemby SE, Lee VM-Y, Eberwine JH, Trojanowski JQ. Expression profile of transcripts in Alzheimer's disease tangle-bearing CA1 neurons. Ann Neurol 48:77-87, 2000.

136. Hemby SE, Ginsberg SD, Brunk B, Arnold SE, Trojanowski JQ, Eberwine JH. Gene expression profile for schizophrenia: discrete neuron transcription patterns in the entorhinal cortex. Arch Gen Psychiatry 59:631-640, 2002.

137. Hemby SE, Trojanowski JQ, Ginsberg SD. Neuron-specific agerelated decreases in dopamine receptor subtype mRNAs. J Comp Neurol 456:176-183, 2003.

138. Mufson EJ, Counts SE, Ginsberg SD. Single cell gene expression profiles of nucleus basalis cholinergic neurons in Alzheimer's disease. Neurochem Res 27:1035-1048, 2002.

139. Eberwine J, Yeh H, Miyashiro K, Cao Y, Nair S, Finnell R, et al. Analysis of gene expression in single live neurons. Proc Natl Acad Sci USA 89:3010-3014, 1992.

140. Eberwine J, Kacharmina JE, Andrews C, Miyashiro K, McIntosh $\mathrm{T}$, Becker K, et al. mRNA expression analysis of tissue sections and single cells. J Neurosci 21:8310-8314, 2001.

141. Eberwine J, Belt B, Kacharmina JE, Miyashiro K. Analysis of subcellularly localized mRNAs using in situ hybridization, mRNA amplification, and expression profiling. Neurochem Res 27:1065-1077, 2002.

142. van Gelder R, von Zastrow M, Yool A, Dement W, Barchas J, Eberwine J. Amplified RNA (aRNA) synthesized from limited quantities of heterogeneous cDNA. Proc Natl Acad Sci USA 87:1663-1667, 1990.

143. Cheetham JE, Coleman PD, Chow N. Isolation of single immunohistochemically identified whole neuronal cell bodies from post-mortem human brain for simultaneous analysis of multiple gene expression. J Neurosci Methods 77:43-48, 1997.

144. Chow N, Cox C, Callahan LM, Weimer JM, Guo L, Coleman PD. Expression profiles of multiple genes in single neurons of Alzheimer's disease. Proc Natl Acad Sci USA 95:9620-9625, 1998.

145. Mufson EJ, Counts SE, Che S, Ginsberg SD. Neuronal gene expression profiling: uncovering the molecular biology of neurodegenerative disease. Prog Neurobiol (in press).

146. Ginsberg SD, Mirnics K. Functional genomics methodologies. Prog Neurobiol (in press). 
147. Dafforn A, Chen P, Deng G, Herrler M, Iglehart D, Koritala S, et al. Linear mRNA amplification from as little as 5 ng total RNA for global gene expression analysis. BioTechniques 37:854-857, 2004.

148. Kurn N, Chen P, Heath JD, Kopf-Sill A, Stephens KM, Wang S. Novel isothermal, linear nucleic acid amplification systems for highly multiplexed applications. Clin Chem 51:1973-1981, 2005.

149. Che S, Ginsberg SD. Amplification of transcripts using terminal continuation. Lab Invest 84:131-137, 2004.

150. Che S, Ginsberg SD. RNA amplification methodologies. In: Trends in RNA research. Hauppauge, NY: Nova Science Publishing (in press).

151. Brown PO, Botstein D. Exploring the new world of the genome with DNA microarrays. Nat Genet 21:33-37, 1999.

152. Eisen MB, Brown PO. DNA arrays for analysis of gene expression. Methods Enzymol 303:179-205, 1999.

153. Schena M, Shalon D, Davis RW, Brown PO. Quantitative monitoring of gene expression patterns with a complementary DNA microarray. Science 270:467-470, 1995.

154. Lockhart DJ, Dong H, Byrne MC, Follettie MT, Gallo MV, Chee MS, et al. Expression monitoring by hybridization to high density oligonucleotide arrays. Nat Biotechnol 14:1675-1680, 1996.

155. Olson NE. The microarray data analysis process: from raw data to biological significance. NeuroRx 3:371-381, 2006.

156. Almudevar A, Klebanov LB, Qiu X, Salzman P, Yakovlev AY. Utility of correlation measures in analysis of gene expression. NeuroRx 3:382-393, 2006.

157. Gygi SP, Rochon Y, Franza BR, Aebersold R. Correlation between protein and mRNA abundance in yeast. Mol Cell Biol 19:1720-1730, 1999.

158. Ginsberg SD, Galvin JE, Chiu T-S, Lee VM-Y, Masliah E, Trojanowski JQ. RNA sequestration to pathological lesions of neurodegenerative disorders. Acta Neuropathol 96:487-494, 1998.

159. Topaloglu H, Sarnat HB. Acridine orange-RNA fluorescence maturing neurons in the perinatal rat brain. Anat Rec 224:88-93, 1989.

160. Tatton NA, Kish SJ. In situ detection of apoptotic nuclei in the substantia nigra compacta of 1-methyl-4-phenyl-1,2,3,6-tetrahydropyridine-treated mice using terminal deoxynucleotidyl transferase labelling and acridine orange staining. Neuroscience 77: 1037-1048, 1997.

161. Eikelenboom P, Veerhuis R. The role of complement and activated microglia in the pathogenesis of Alzheimer's disease. Neurobiol Aging 17:673-680, 1996.

162. Sarnat HB, Curry B, Rewcastle NB, Trevenen CL. Gliosis and glioma distinguished by acridine orange. Can J Neurol Sci 14: 31-35, 1987.

163. Burbach GJ, Dehn D, Nagel B, Del Turco D, Deller T. Laser microdissection of immunolabeled astrocytes allows quantification of astrocytic gene expression. J Neurosci Methods 138:141148,2004

164. Burbach GJ, Dehn D, Del Turco D, Staufenbiel M, Deller T. Laser microdissection reveals regional and cellular differences in GFAP mRNA upregulation following brain injury, axonal denervation, and amyloid plaque deposition. Glia 48:76-84, 2004.

165. Harrison PJ, Barton AJ, Najlerahim A, McDonald B, Pearson RC. Regional and neuronal reductions of polyadenylated messenger RNA in Alzheimer's disease. Psychol Med 21:855-866, 1991.

166. Griffin WS, Ling C, White CL, Morrison-Bogorad M. Polyadenylated messenger RNA in paired helical filament-immunoreactive neurons in Alzheimer's disease. Alzheimer Dis Assoc Dis 4:69-78, 1990.

167. Liu F, Grundke-Iqbal I, Iqbal K, Gong CX. Contributions of protein phosphatases PP1, PP2A, PP2B and PP5 to the regulation of tau phosphorylation. Eur J Neurosci 22:1942-1950, 2005.

168. Vogelsberg-Ragaglia V, Schuck T, Trojanowski JQ, Lee VM. PP2A mRNA expression is quantitatively decreased in Alzheimer's disease hippocampus. Exp Neurol 168:402-412, 2001.

169. Goedert M, Jakes R, Qi Z, Wang JH, Cohen P. Protein phosphatase $2 \mathrm{~A}$ is the major enzyme in brain that dephosphorylates $\mathrm{t}$ protein phosphorylated by proline-directed protein kinases or cyclic AMP-dependent protein kinase. J Neurochem 65:2804-2807, 1995.
170. Joyce JN, Kaeger C, Ryoo H, Goldsmith S. Dopamine D2 receptors in the hippocampus and amygdala in Alzheimer's disease. Neurosci Lett 154:171-174, 1993.

171. Ryoo HL, Joyce JN. Loss of dopamine D2 receptors varies along the rostrocaudal axis of the hippocampal complex in Alzheimer's disease. J Comp Neurol 348:94-110, 1994.

172. Rinne JO, Lonnberg P, Marjamaki P. Age-dependent decline in human brain dopamine D1 and D2 receptors. Brain Res 508:349$352,1990$.

173. Volkow ND, Wang GJ, Fowler JS, Ding YS, Gur RC, Gatley J, et al. Parallel loss of presynaptic and postsynaptic dopamine markers in normal aging. Ann Neurol 44:143-147, 1998.

174. Amenta F, Mignini F, Ricci A, Sabbatini M, Tomassoni D, Tayebati SK. Age-related changes of dopamine receptors in the rat hippocampus: a light microscope autoradiography study. Mech Aging Dev 122:2071-2083, 2001.

175. Gutala RV, Reddy PH. The use of real-time PCR analysis in a gene expression study of Alzheimer's disease post-mortem brains. J Neurosci Methods 132:101-107, 2004.

176. Callahan LM, Vaules WA, Coleman PD. Quantitative decrease in synaptophysin message expression and increase in cathepsin D message expression in Alzheimer's disease neurons containing neurofibrillary tangles. J Neuropathol Exp Neurol 58:275-287, 1999.

177. Heffernan JM, Eastwood SL, Nagy Z, Sanders MW, McDonald B, Harrison PJ. Temporal cortex synaptophysin mRNA is reduced in Alzheimer's disease and is negatively correlated with the severity of dementia. Exp Neurol 150:235-239, 1998.

178. Shimohama S, Kamiya S, Taniguchi T, Akagawa K, Kimura J. Differential involvement of synaptic vesicle and presynaptic plasma membrane proteins in Alzheimer's disease. Biochem Biophys Res Commun 236:239-242, 1997.

179. Sze CI, Troncoso JC, Kawas C, Mouton P, Price DL, Martin LJ. Loss of the presynaptic vesicle protein synaptophysin in hippocampus correlates with cognitive decline in Alzheimer's disease. J Neuropathol Exp Neurol 56:933-944, 1997.

180. Sze CI, Bi H, Kleinschmidt-DeMasters BK, Filley CM, Martin LJ. Selective regional loss of exocytotic presynaptic vesicle proteins in Alzheimer's disease brains. J Neurol Sci 175:81-90, 2000.

181. Cataldo AM, Paskevich PA, Kominami E, Nixon RA. Lysosomal hydrolases of different classes are abnormally distributed in brains of patients with Alzheimer's disease. Proc Natl Acad Sci USA 88:10998-11002, 1991.

182. Cataldo AM, Barnett JL, Berman SA, Li J, Quarless S, Bursztajn $\mathrm{S}$, et al. Gene expression and cellular content of cathepsin D in Alzheimer's disease brain: evidence for early up-regulation of the endosomal-lysosomal system. Neuron 14:671-680, 1995.

183. Cataldo AM, Barnett JL, Picroni C, Nixon RA. Increased neuronal endocytosis and protease delivery to early endosomes in sporadic Alzheimer's disease: neuropathologic evidence for a mechanism of increased $\beta$-amyloidogenesis. J Neurosci 17:61426151, 1997.

184. Yu WH, Cuervo AM, Kumar A, Peterhoff CM, Schmidt SD, et al. Macroautophagy: a novel $\beta$-amyloid peptide-generating pathway activated in Alzheimer's disease. J Cell Biol 171:87-98, 2005

185. Nixon RA. Endosome function and dysfunction in Alzheimer's disease and other neurodegenerative diseases. Neurobiol Aging 26:373-382, 2005.

186. Cataldo AM, Hamilton DJ, Barnett JL, Paskevich PA, Nixon RA. Properties of the endosomal-lysosomal system in the human central nervous system: disturbances mark most neurons in populations at risk to degenerate in Alzheimer's disease. $J$ Neurosci 16:186-199, 1996.

187. Mesulam MM, Mufson EJ, Levey AI, Wainer BH. Cholinergic innervation of cortex by the basal forebrain: cytochemistry and cortical connections of the septal area, diagonal band nuclei, nucleus basalis (substantia innominata), and hypothalamus in the rhesus monkey. J Comp Neurol 214:170-197, 1983.

188. Bartus RT, Dean RL III, Beer B, Lippa AS. The cholinergic hypothesis of geriatric memory dysfunction. Science 217:408414, 1982. 
189. Baxter MG, Chiba AA. Cognitive functions of the basal forebrain. Curr Opin Neurobiol 9:178-183, 1999.

190. Davies P, Maloney AJ. Selective loss of central cholinergic neurons in Alzheimer's disease. Lancet 2:1403, 1976.

191. Bierer LM, Haroutunian V, Gabriel S, Knott PJ, Carlin LS, Purohit DP, et al. Neurochemical correlates of dementia severity in Alzheimer's disease: relative importance of the cholinergic deficits. J Neurochem 64:749-760, 1995.

192. Auld DS, Kornecook TJ, Bastianetto S, Quirion R. Alzheimer's disease and the basal forebrain cholinergic system: relations to beta-amyloid peptides, cognition, and treatment strategies. Prog Neurobiol 68:209-245, 2002.

193. Galvin JE, Ginsberg SD. Expression profiling in the aging brain: a perspective. Aging Res Rev 4:529-547, 2005.

194. Galvin JE, Ginsberg SD. Expression profiling and pharmacotherapeutic development in the central nervous system. Alzheimer Dis Assoc Disord 18:264-269, 2004.

195. Mesulam M, Shaw P, Mash D, Weintraub S. Cholinergic nucleus basalis tauopathy emerges early in the aging-MCI-AD continuum. Ann Neurol 55:815-828, 2004.

196. Counts SE, Mufson EJ. The role of nerve growth factor receptors in cholinergic basal forebrain degeneration in prodromal Alzheimer's disease. J Neuropathol Exp Neurol 64:263-272, 2005.

197. Mufson EJ, Ma SY, Cochran EJ, Bennett DA, Beckett LA, Jaffar $\mathrm{S}$, et al. Loss of nucleus basalis neurons containing trkA immunoreactivity in individuals with mild cognitive impairment and early Alzheimer's disease. J Comp Neurol 427:19-30, 2000.

198. Bennett DA, Wilson RS, Schneider JA, Evans DA, Beckett LA, Aggarwal NT, et al. Natural history of mild cognitive impairment in older persons. Neurology 59:198-205, 2002.

199. King ME, Gamblin TC, Kuret J, Binder LI. Differential assembly of human tau isoforms in the presence of arachidonic acid. $\mathrm{J} \mathrm{Neu}$ rochem $74: 1749-1757,2000$.

200. Levy SF, Leboeuf AC, Massie MR, Jordan MA, Wilson L, Feinstein SC. Three- and four-repeat tau regulate the dynamic instability of two distinct microtubule subpopulations in qualitatively different manners: implications for neurodegeneration. $J$ Biol Chem 280:13520-13528, 2005.
201. Chambers CB, Lee JM, Troncoso JC, Reich S, Muma NA. Overexpression of four-repeat tau mRNA isoforms in progressive supranuclear palsy but not in Alzheimer's disease. Ann Neurol 46:325-332, 1999.

202. de Silva R, Lashley T, Gibb G, Hanger D, Hope A, Reid A, et al. Pathological inclusion bodies in tauopathies contain distinct complements of tau with three or four microtubule-binding repeat domains as demonstrated by new specific monoclonal antibodies. Neuropathol Appl Neurobiol 29:288-302, 2003.

203. Arai T, Ikeda K, Akiyama H, Tsuchiya K, Iritani S, Ishiguro K, et al. Different immunoreactivities of the microtubule-binding region of tau and its molecular basis in brains from patients with Alzheimer's disease, Pick's disease, progressive supranuclear palsy and corticobasal degeneration. Acta Neuropathol (Berl) 105:489-498, 2003.

204. Fujino Y, Wang DS, Thomas N, Espinoza M, Davies P, Dickson DW. Increased frequency of argyrophilic grain disease in Alzheimer disease with 4R tau-specific immunohistochemistry. J Neuropathol Exp Neurol 64:209-214, 2005.

205. Zhukareva V, Shah K, Uryu K, Braak H, Del Tredici K, Sundarraj $\mathrm{S}$, et al. Biochemical analysis of tau proteins in argyrophilic grain disease, Alzheimer's disease, and Pick's disease: a comparative study. Am J Pathol 161:1135-1141, 2002.

206. Mufson EJ, Ginsberg SD, Ikonomovic MD, DeKosky ST. Human cholinergic basal forebrain: chemoanatomy and neurologic dysfunction. J Chem Neuroanat 26:233-242, 2003.

207. Sofroniew MV, Howe CL, Mobley WC. Nerve growth factor signaling, neuroprotection, and neural repair. Anпи Rev Neurosci 24:1217-1281, 2001

208. Counts SE, Nadeem M, Wuu J, Ginsberg SD, Saragovi HU, Mufson EJ. Reduction of cortical TrkA but not p75(NTR) protein in early-stage Alzheimer's disease. Ann Neurol 56:520-531, 2004.

209. Colantuoni C, Purcell AE, Bouton CM, Pevsner J. High throughput analysis of gene expression in the human brain. $J$ Neurosci Res 59:1-10, 2000.

210. Serafini T. Of neurons and gene chips. Curr Opin Neurobiol 9:641-644, 1999. 